\title{
MORPHOMETRIC ANALYSIS OF CALCIUM OXALATE RAPHIDES AND ASSESSMENT OF THEIR TAXONOMIC VALUE FOR ARCHAEOLOGICAL MICROFOSSIL STUDIES
}

\author{
Alison Crowther ${ }^{1,2}$ \\ 1. School of Social Science \\ The University of Queensland \\ St Lucia QLD 4072 Australia \\ 2. Department of Archaeology \\ University of Sheffield \\ Northgate House, West Street \\ Sheffield S1 4ET United Kingdom \\ Email: alison.crowther@gmail.com
}

\begin{abstract}
Plant microfossil analysis is an important tool for understanding prehistoric plant exploitation in the Pacific region, where macrobotanical remains rarely survive. Calcium oxalate raphides (needle-shaped plant crystals) have been identified in several tool-residue and sediment microfossil studies and in some cases classified to genera or species, yet their diagnostic potential has not been thoroughly assessed through quantitative reference collection analyses. This study presents a morphometric analysis of raphides from key Pacific economic plants including aroids, yams, palms, pandanus, banana (Musa), Heliconia and Cordyline, using both light and scanning electron microscopy. Variation in raphide size and shape was compared intra- and inter-taxa to assess whether significant differences exist. Results indicate that raphide size varies considerably within species, while similar shapes are found in a number of taxa, leaving little scope for taxonomic differentiation. The main exceptions are raphides produced by members of the Araceae (aroids), which may be identified at the genus level owing to their unique morphologies. These results suggest that raphides have some potential to be a useful taxonomic tool in archaeological microand macrobotanical studies, particularly if Colocasia esculenta (taro) and other aroids are present.
\end{abstract}

\section{KEYWORDS}

raphides, calcium oxalate crystals, microfossils, Pacific archaeobotany, microscopy, morphometric analysis

\section{INTRODUCTION}

Reconstructions of the plant exploitation and cultivation practices of prehistoric Pacific peoples have become increasingly reliant on studies of microbotanical remains recovered from site sediments and tool-use residues. Although analyses of starch granules, phytoliths and pollen are 
driving these developments (e.g. Fullagar et al. 2006; Lentfer and Green 2004; Therin et al. 1999), previously overlooked microfossil types such as calcium oxalate raphides are now receiving wider attention (e.g. Crowther 2005, in press; Horrocks and Barber 2005; Horrocks and Bedford 2005; Horrocks and Nunn 2007; Horrocks and Weisler 2006; Horrocks et al. 2007, 2008a, 2008b).

Raphides are needle-shaped calcium oxalate crystals that are produced by higher plants for defence, calcium storage and structural strength (Franceschi and Horner 1980; Franceschi and Nakata 2005; Nakata 2003). Owing to their inorganic properties, they have potential to be preserved in archaeological sites where other plant remains, particularly soft tissues, generally do not survive. Of significance to Pacific archaeobotany is the fact that raphides are highly abundant in aroids (Araceae) such as taro (Colocasia esculenta), swamp taro (Cyrtosperma chamissonis) and elephant ear taro (Alocasia macrorrhiza), which are major food staples across the region. Raphides have therefore become an important indicator of aroids in the archaeological record, and have been identified to this group in several microfossil and tool-residue studies (see references cited above). These studies have rarely accounted for the fact that raphides are also produced by many other economically important plants, including the yams, palms, bananas, and pandanus, to name just a few (see review by Crowther in press). If raphides are to continue playing a role in Pacific archaeobotanical studies, their diagnostic potential must be assessed and reliable classification keys must be established.

The diagnostic value of raphides was first demonstrated by Loy et al. (1992; see also Loy 1994), who investigated whether their presence in association with starch granules on stone tools could aid in residue identification. They determined that raphides are particularly abundant in aroids and either much rarer or absent in the other plants analysed (including various yams, sago, cycad and sweet potato) (Loy et al. 1992:910). Even though this observation was based on the analysis of a limited range of reference materials, the presence of large quantities of raphides in residue or microfossil assemblages has been interpreted in several studies since as indicating the probable presence of aroids (e.g. Crowther 2005; Horrocks and Bedford 2005; Horrocks and Nunn 2007; Horrocks and Weisler 2006; Horrocks et al. 2008b). Quantitative comparisons of raphide concentrations between economic plants are required to assess whether abundance has any diagnostic value in these cases.

Secondly, Loy et al. (1992) noted that the size, cross-section and termination shape of raphides produced by different species varied so as to be 'seemingly distinctive ... to genus' (Loy et al. 1992:900-910). The specific configuration of these morphological attributes were only briefly described (Loy et al. 1992:900, 905-906; see summary in Table 1), and have rarely been incorporated into more recent raphide identifications (cf. Fullagar et al. 2006). Finally, Loy et al. (1992:900) observed what they referred to as 'whisker' raphides in aroids, which were defined loosely as very thin, sometimes curved raphides that possibly represent an immature form. Bradbury and Nixon (1998) also described 'thick' (defined as $\sim 3 \mu \mathrm{m}$ wide) and 'thin' $(\sim 0.5 \mu \mathrm{m}$ wide) raphides within some aroids. Whisker raphides are one of the most common raphide types observed in microfossil assemblages from the Pacific region and have been interpreted in all cases as indicating the presence of aroids (e.g. Crowther 2005; Horrocks and Bedford 2005; Horrocks and Barber 2005; Horrocks and Nunn 2007; Loy et al. 1992), even though it is presently unclear if they represent a distinctive aroid type. Although the findings of Loy et al. (1992) were essentially preliminary, in that they were based on light microscopic observations of raphides from only the storage organs (i.e. roots and tubers) of a limited range of taxa, they nevertheless highlighted the potential for differentiating raphides based on morphometric characteristics.

Subsequent studies have discussed limitations imposed on raphide analyses by the often fragmented and degraded state of archaeological crystals (e.g. Crowther 2005:64-65; Horrocks and Bedford 2005:70-71). For example, morphologically distinctive features such as terminations may not be present on archaeological raphides and size can be difficult to estimate from broken crystals. While cross-sectional shape has been observed in some studies using light microscopy (e.g. Fullagar et al. 2006:605; Loy et al. 1992), raphides are often too small for such features to be resolved unambiguously with a light microscope (see also discussion in Horrocks and Nunn 
Table 1. Summary of Loy et al.'s (1992) description of raphides from various aroid and yam species

\begin{tabular}{|c|c|c|c|c|}
\hline \multirow{2}{*}{ Species } & \multicolumn{2}{|c|}{ Termination } & \multirow{2}{*}{$\begin{array}{l}\text { Cross- } \\
\text { section }\end{array}$} & \multirow{2}{*}{ Other descriptions } \\
\hline & End A & End B & & \\
\hline Aroids (general) & $\mathrm{ns}^{\mathrm{a}}$ & ns & Square & Small "whisker" raphides. \\
\hline Alocasia macrorrhiza & Pointed & Pointed & Square & Elongate \\
\hline $\begin{array}{l}\text { Amorphophallus } \\
\text { campanulatus }\end{array}$ & Pointed & Square & $\begin{array}{l}\text { ' } X \text { '-shaped at } \\
\text { pointed end }\end{array}$ & Asymmetric \\
\hline Colocasia affinis & ns & ns & ns & $\begin{array}{l}\text { Small and simple } \\
\text { raphides. }\end{array}$ \\
\hline Colocasia esculenta & $\begin{array}{l}\text { Sharply } \\
\text { tapered }\end{array}$ & $\begin{array}{l}\text { Short double- } \\
\text { bevelled }\end{array}$ & Square & $\begin{array}{l}\text { Short, small, simple lath- } \\
\text { like. }\end{array}$ \\
\hline Colocasia fallax & Blunt & Blunt & ns & Centrally constricted. \\
\hline Colocasia gigantea & ns & ns & Square & $\begin{array}{l}\text { Small, simple, lath-like, } \\
\text { whisker raphides }>200 \\
\mu \mathrm{m} \text { long. }\end{array}$ \\
\hline $\begin{array}{l}\text { Cyrtosperma } \\
\text { chamissonis }\end{array}$ & ns & ns & ns & Large, well developed. \\
\hline Xanthosoma sagitiffolium & ns & ns & ns & Large, well developed. \\
\hline Dioscorea esculenta & Pointed & Pointed & Round & $\begin{array}{l}\text { Long, smoothly tapered, } \\
\text { larger than aroid raphides. }\end{array}$ \\
\hline
\end{tabular}

2007:742). One avenue that microfossil analysts have previously overlooked is to use scanning electron microscopy (SEM) for higher resolution imaging of morphology, as discussed below.

To address these issues, a modern reference collection of economically important plants from the Pacific Islands was analysed to assess whether raphides from different plant taxa can be differentiated on the basis of morphometric features. The study aimed not only to provide descriptions of raphides across a range of taxa using both light and scanning electron microscopy, but also to make quantitative statements about the degree of intra- and inter-species variability in size and shape. An additional objective was to clarify morphological descriptions of aroid raphides by Loy et al. (1992) and to provide further comment on the possible taxonomic significance of whisker raphides. Ideally, raphides from specimens growing in different environments would also be compared, however such analyses were beyond the scope of this study. The results of the study are briefly compared with other published raphide descriptions (e.g. Bradbury and Nixon 1998; Sakai and Hanson 1974) in order to assess the potential for environmentally-determined variation.

\section{RAPHIDE MORPHOMETRIC VARIATION}

Raphides are one of five types of calcium oxalate crystals produced by higher plants. Other crystal types include rosette-shaped druses, pencil-shaped styloids, block-shaped aggregates called crystal sand, and prisms (Horner and Wagner 1995). Raphides form in bundles of tens to thousands of crystals in specialised idioblast cells, from which they can be ejected as a defence mechanism (e.g. Arnott and Pautard 1970; Gardner 1994; Middendorf 1983; Sunell and Healey 1981). They can occur in any plant organ or tissue, including stems, leaves, roots, tubers and seeds (Horner and Wagner 1995).

Current evidence suggests that calcium oxalate crystal production is at least partly genetically controlled (Kausch and Horner 1982) and that the shape and location of crystals within specific tissues may have taxonomic significance (e.g. Bouropoulos et al. 2001; Cervantes-Martinez et al. 2005; Hartl et al. 2007; Horner and Wagner 1995; Lersten and Horner 2000, 2008; Webb 1999). Morphometric studies of individual crystals are limited and have mainly been undertaken on druses within the Cactaceae (e.g. Jones and Bryant 1992; Monje and Baran 2002). These 
studies have shown that druses produced by different cactus genera may be differentiated based on size and shape, with the latter being the more significant variable (Jones and Bryant 1992; Monje and Baran 2002). Monje and Baran (2002) demonstrated that druse morphologies are determined by chemical composition, so that some cactus groups produce exclusively calcium oxalate monohydrate druses, which have a more stellate appearance owing to their monoclinic crystal system, while others produce calcium oxalate dihydrate druses with typically tetragonal crystallites. Crystal size on the other hand tends to vary more within a single plant, depending on the function of the cell or tissue in which it formed as well as the amount of calcium available during crystal formation (Franceschi and Nakata 2005). Jones and Bryant (1992:234-236) found that in the stem of a single cactus species there was a consistent reduction in the size of druses from the central pith region towards the outer epidermis/hypodermis, and that size was therefore not as useful for taxonomic differentiation as morphology. They also found that druses from the stem tissues of species growing in different habitats were very consistent in size and shape, indicating that these characteristics are more genetically than environmentally determined (Jones and Bryant 1992:236).

Botanical studies report that higher plants produce at least four different morphological raphide types, referred to here as Types I-IV (e.g. Cody and Horner 1983:328; Horner and Tilton 1980; Horner and Wagner 1995; see also Crowther in press). These types are defined based on sectional and termination shape, as shown in Figure 1, as well as crystallographic characteristics such as twinning. Type I is the most common form, and comprises four-sided single crystals with two symmetrical pointed ends. Type II raphides, which are also four-sided, have one pointed and one bidentate or forked end (Prychid and Rudall 1999:726). This type of raphide has so far only been recorded in the Vitaceae (Cody and Horner 1983; Webb 1999). The bidentate end is formed by crystal twinning, which represents a dislocation or change in orientation of the crystal lattice along a plane within the raphide (Arnott 1981; Arnott and Webb 2000:133).

Mature Type III crystals have six to eight sides and symmetrical pointed ends (Tilton and Horner 1980). Owing to their multi-faceted surface, they are sometimes described as appearing elliptical or circular in cross-section when viewed under a light microscope (Prychid and Rudall 1999:726; Loy et al. 1992:900). Type III raphides have been reported in the Agavaceae (e.g. Cordyline spp.) (Wattendorff 1976), Typhaceae (Horner et al. 1981), Hyacinthaceae (Tilton and Horner 1980) and Dioscoreaceae (Crowther in press). Horner et al. (1981) demonstrated in a study of raphides from Typha angustifolia L. (Typhaceae) that this type of crystal develops in several morphological stages: immature four-sided crystals with chisel-shaped ends pass through a twelve-sided intermediate phase before further growth and extension along different margins produces a mature crystal that is hexagonal at its now pointed ends and octagonal in the central

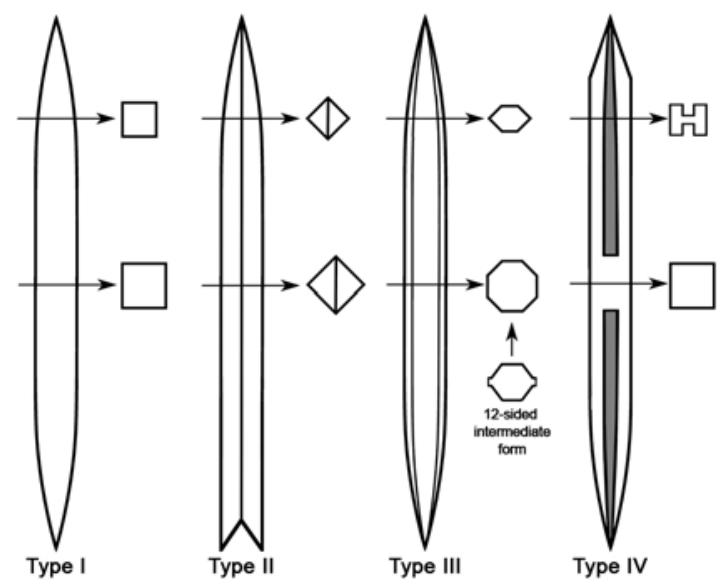

Figure 1. Diagram of the four known raphide morphological types, showing different terminations and cross-sections (after Horner and Wagner 1995:58). 
region (see Figure 1). Immature crystals of this type, if present in a microfossil assemblage, may therefore be confused with Type I raphides. Wattendorff (1976:304) noted that Type III raphides have lateral 'wings' at the two smaller-angled edges, owing to unequal angles between the facets. This feature appears to correlate with the intermediate twelve-sided form described by Horner et al. (1981), as illustrated in cross-section in Figure 1.

Type IV raphides are twinned crystals with H-shaped cross-sections and asymmetrical ends (e.g. Bradbury and Nixon 1998; Kostman and Franceschi 2000). One end of this raphide type terminates at a sharp point while the other is blunt or wedge-shaped. A medial groove along two of the crystal's opposite faces gives this type its overall H-shaped cross-section, although the solid mid-point at which the groove meets is four-sided and sometimes visible under polarised light. Type IV raphides can also develop barbs or wing-like projections on their pointed ends as they mature (Bradbury and Nixon 1998:614; Prychid and Rudall 1999:726; Prychid et al. in press; Sakai et al. 1972). The groove in some species (e.g. Pistia stratiotes) is asymmetrical, being narrower on one side of the central bridge than the other (Kostman and Franceschi 2000:173). The H-shaped form is thought to be unique to raphides from the Araceae (Prychid and Rudall 1999; Prychid et al. in press), which may be of considerable value for identifying aroid crystals in archaeological assemblages. Barbs have however been noted in other taxa, albeit rarely (Cody and Horner 1983:319).

\section{ASSESSING TAXONOMIC SIGNIFICANCE}

The simplest method of assigning taxonomic significance to a microfossil is to determine whether any potentially diagnostic morphometric types occur within a plant taxon. For a raphide type to be diagnostic, it must occur in all members of a taxon at a certain level (e.g. family, genus, species) but be absent from all non-members (Madella et al. 2005). Madella et al. (2005) thereby distinguish diagnostic from observed, which refers to a type known to be present in, but not necessarily specific to, a particular taxon. If taxonomic significance cannot be assigned to a single morphometric type, the frequencies of different types within an assemblage may have significance (Madella et al. 2005; Piperno et al. 2000, 2004). Multivariate analyses of a combination of morphometric variables have also been shown to be useful for discriminating taxa, particularly when there appear to be few or only minor differences between species (Torrence 2006:135). Using these methods, for example, starch granules have been confidently differentiated and identified in several comparative and archaeological studies (e.g. Loy et al. 1992; Torrence et al. 2004). A key assumption of starch analysis, though, is that taxonomically distinctive granules are produced in storage or reserve organs (which are generally also the most economically useful), while other organs such as leaves and stems produce mainly small, non-diagnostic types (e.g. Fullagar et al. 2006; Therin et al. 1997; Torrence 2006:128). Species identification of starch or other microfossil types would be considerably more difficult if greater intra-species variation occurred, unless it can be determined from which part of the plant the microfossils are derived. The process of establishing a taxonomic key for raphides must therefore begin by assessing whether significant morphometric variation exists within a plant before comparing variation between species.

\section{METHODS AND MATERIALS}

Raphides from a total of 20 plant species representing seven families were examined in this study (Table 2). These species were selected because of their likely economic importance during Pacific prehistory (e.g. Barrau 1958; Hather 1992; Massal and Barrau 1965; Whistler 1991; Yen 1974, 1976, 1991), as well as to represent a variety of known raphide-bearing families. Some aroid species that are either recent introductions to the Pacific (e.g. Xanthosoma sagittifolium) or not presently regarded as food sources (e.g. Amorphophallus blumei, Cyrtosperma johnstonii) were included for comparative purposes. Samples were collected either in Indonesia and Papua New Guinea by Dr Carol Lentfer (The University of Queensland), from gardens at The University 
Table 2. List of plants and corresponding organs from which raphides were extracted and examined in this study

\begin{tabular}{|c|c|c|c|}
\hline Family & Species & $\begin{array}{l}\text { Sample } \\
\text { Number }\end{array}$ & Organ \\
\hline \multirow[t]{7}{*}{ Araceae } & $\begin{array}{l}\text { Alocasia macrorrhiza (L.) G. Don var. } \\
\text { rubra (Hassk.) Furtado }\end{array}$ & B05021 & Flower, leaf, petiole, root, stem \\
\hline & $\begin{array}{l}\text { Amorphophallus blumei (Schott.) } \\
\text { Engl. }\end{array}$ & B05019 & Bulbil, leaf, petiole, root, tuber \\
\hline & $\begin{array}{l}\text { Amorphophallus campanulatus Blume } \\
\text { (syn. paeonifolius) }\end{array}$ & IV-69-15 & Tuber \\
\hline & Colocasia esculenta (L.) Schott & B05029 & Leaf, petiole, root, tuber \\
\hline & Cyrtosperma chamissonis Schott & IV-69-5 & Tuber \\
\hline & Cyrtosperma johnstonii (Bull) NE Br. & B05089 & Flower, leaf, petiole, root, tuber \\
\hline & Xanthosoma sagittifolium (L.) Schott & B05025 & Leaf, petiole, root, stem \\
\hline \multirow[t]{3}{*}{ Arecaceae } & Caryota mitis Lour. & B05179 & $\begin{array}{l}\text { Fruit, leaf, rachis, root, seed, } \\
\text { stem }\end{array}$ \\
\hline & Caryota rumphiana Blume ex Martelli & B05160 & Leaf, rachis, stem, wood \\
\hline & Cocos nucifera L. cv. Pinang & B05177 & Leaf, rachis, root, wood \\
\hline \multirow[t]{3}{*}{ Dioscoreaceae } & Dioscorea bulbifera L. & B05086 & Bulbil, leaf, root, stem, tuber \\
\hline & Dioscorea esculenta (Lour.) Burkill & B05085 & Leaf, stem, tuber \\
\hline & Dioscorea hispida Dennst. & B05087 & Leaf, petiole, stem, tuber \\
\hline Heliconiaceae & Heliconia indica Lam. & B05287 & Flower, fruit, leaf, root, tuber \\
\hline Laxmanniaceae & Cordyline terminalis (L.) Kunth & Local & Leaf, petiole, root, stem \\
\hline \multirow[t]{3}{*}{ Musaceae } & $\begin{array}{l}\text { Musa acuminata ssp. banksii (F. } \\
\text { Muell.) Simmonds }\end{array}$ & ES6 & Bract, fruita ${ }^{\mathrm{a}}$, leaf, petiole \\
\hline & Musa ingens Simmonds & WH2 & $\begin{array}{l}\text { Bract, flower, leaf, petiole, } \\
\text { pseudo-stem }\end{array}$ \\
\hline & Musa maclayi F. Muell. & MB5 & Bract, flower, fruit ${ }^{\mathrm{a}}$, leaf, petiole \\
\hline \multirow[t]{2}{*}{ Pandanaceae } & Pandanus dubius Spreng & B05141 & Leaf, root, wood \\
\hline & Pandanus tectorius Soland. ex Park. & B05138 & Leaf, root, wood \\
\hline \multicolumn{4}{|c|}{ a Including seed and skin } \\
\hline \multicolumn{4}{|c|}{ Sample prefix provenance key: } \\
\hline \multicolumn{4}{|c|}{ B - Bogor Botanical Gardens, Indonesia } \\
\hline \multicolumn{4}{|c|}{ IV - Loy collection, provenance unknown } \\
\hline \multicolumn{4}{|c|}{ ES/WH/MB - Papua New Guinea } \\
\hline
\end{tabular}

of Queensland, Australia by the author, or were from Dr Tom Loy's reference collection held at UQ (see Loy 1994). It should be noted that for the sake of simplicity all vegetative storage organs (e.g. tuber, corm, root and rhizome) are referred to throughout this study as tubers and were collectively analysed as such to facilitate their comparison. Likewise, pseudo-stems were included in the stem group.

Raphides were extracted by placing a small sample of tissue in a $1.5 \mathrm{ml}$ vial, macerating the tissue in $70 \%$ ethanol for approximately 48 hours, then mechanically disrupting the tissue with a dental pick to free the raphides (after Webb et al. 1995). The ethanol-raphide suspension was agitated and a 50-100 $\mu 1$ aliquot removed to a microscope slide and allowed to air dry. A coverslip was applied and tacked down at each corner with clear nail polish. Slides were hydrated with water and examined in plane and cross-polarised light using an Olympus BX60 transmitted light microscope at magnifications between $\times 200$ and $\times 1000$ without the use of oil immersion.

Maximum length and width measurements for 50 randomly selected whole raphides were recorded per organ for each species. Length was measured to the nearest micron while width was measured to the nearest $0.5 \mu \mathrm{m}$. In cases where raphides were rare, multiple slides were prepared and an equal portion was randomly selected from each. If it was still not possible to record 50 using this method, all raphides on these slides were measured without replacement. Morphological features visible with a light microscope, such as termination shape and symmetry, grooves, bridges, facets, or wings were also described. Whisker raphides, which are defined here 
as raphides of any length with widths less than $0.5 \mu \mathrm{m}$, were excluded from the sample as it was generally difficult to determine if they were whole or fragmented owing to their fineness. Rather, each slide was scanned in transects to determine and separately record the maximum size of any whisker raphides present. The relative abundance of raphides in each sample was estimated on a qualitative scale from absent to very abundant (c. $>500$ per slide) with intermediate levels of rare (c. $<20$ per slide), common (c. $<100$ per slide), and abundant (c. $<500$ per slide). It is noted that these estimates of abundance are only indicative because sample sizes, including both the amount of tissue sampled from each organ and the amount of residue applied to each slide, were not consistent.

Classification of raphides to morphological type using SEM could only be undertaken on a small number of samples from each family owing to restricted access to instrumentation. All other species in each family were therefore tentatively classified to the same type based on the assumption that form is family-specific (see Horner and Wagner 1995 for discussion). Samples were prepared for SEM by applying a $50 \mu 1$ aliquot of suspended raphide extract to a glass coverslip on an aluminum stub. The samples were air dried and coated with platinum using an EIKO IB-5 sputter coater for five minutes at $6 \mathrm{~mA}$, which produced a $15 \mathrm{~nm}$ coating over the specimen surface. Raphides were examined at the Centre for Microscopy and Microanalysis, The University of Queensland, using a JEOL LV-6460 SEM in high vacuum at an accelerating voltage of $5 \mathrm{kV}$.

\section{Statistical procedures}

A multivariate analysis of variance (MANOVA) was undertaken to assess the degree of variation in raphide size (length and width) within and between plant species. MANOVA tests the null hypothesis $\left(\mathrm{H}_{\mathrm{o}}\right)$ that all sample means are equal at a chosen confidence level (in this case $95 \%$ or where $p=0.05$ ). The MANOVA was undertaken to test the experimental hypothesis that significant differences in raphide size occur between species but not within species in each morphological group. Within species tests were performed by comparing raphide sizes from each organ analysed for a particular plant. Amorphophallus campanulatus and Cyrtosperma chamissonis were excluded from this analysis because raphides from only a single organ were analysed (the tuber in both cases). Inter-species comparisons were made on an organ-to-organ basis so that, for example, all leaf samples are compared across species within each morphological group. This approach was considered more statistically and taxonomically meaningful than if each organ from each species was treated as an individual case and compared with all other organs of every species, even though fewer comparisons were thus able to be made. Although morphological variables could also have been included in this statistical model, it was decided to perform separate inter-species comparisons for each morphological group instead to facilitate interpretation of the results. Because Type I and immature Type III raphides are morphologically similar, these groups were combined as a single Type I/III group during this analysis in case they were misclassified. Further research is required to determine if there is a size threshold between immature and mature Type III raphides that can be used to differentiate the two groups.

All statistical analyses were performed using SPSS 13.0 for Macintosh. Before undertaking the multivariate analyses, descriptive statistics of the ranges, minimums, maximums, means and standard deviations were calculated for the length and width variables. The statistical soundness of each sample size was determined using the following equation, which calculates that the sample means are within $5 \%$ of the actual population means at a $90 \%$ confidence level (Madella et al. 2005:254; see also Drennan 1996):

$$
\mathrm{n}_{\min }=\left(\frac{\sigma t}{E R}\right)^{2}
$$

where $\mathrm{n}_{\min }=$ the minimum adequate sample size; 
$\sigma=$ the standard deviation of the sample;

$\mathrm{t}=\mathrm{t}$-score at $90 \%$ confidence $=1.645$; and

$\mathrm{ER}=$ the desired error range (in this case $0.05 \times$ the sample mean).

Species were then grouped by morphological type and box-and-whisker plots comparing raphide lengths within each species were prepared to visualise the degree of variation.

The data were examined for conformity to the multivariate test assumptions and any necessary transformations were applied (see Field 2005:593; Pallant 2005:249). To equalize sample sizes, cases where less than 50 raphides were measured owing to rarity were excluded from the analysis. MANOVA is generally robust to violations of normality except in cases where such deviations are caused by outliers (Pallant 2005:249; Tabachnick and Fidell 1996). Multivariate outliers identified by calculating Mahalanobis distances $(\mathrm{p}>0.001)$ were therefore excluded from the analysis (see Pallant 2005:250-251). Finally, Pillai's Trace statistic was used because of its robustness to modest violations of the test assumptions (Field 2005:594, 599). In addition to the multivariate analyses, follow-up univariate ANOVAs were performed for each dependent variable to determine if length and width contributed differently to any significant differences in size. Univariate outliers more than three standard deviations from the mean were excluded from these analyses (Field 2005:76). Post-hoc comparisons were not undertaken as it was unnecessary in light of the results to determine where significant differences occurred in each case (i.e. which organs within or between species had significantly different means and which formed homogenous sub-sets).

\section{RESULTS}

\section{Morphological classifications}

With the exception of the Pandanaceae and Araceae, all analysed families (Arecaceae, Dioscoreaceae, Heliconiaceae, Laxmanniaceae, and Musaceae) were found to produce Type III raphides. By light microscopy these raphides generally appeared simple and symmetrical, with smoothly-tapered terminations (Figure 2). In most cases sectional shape was not visible by light microscope, although 'wings' were sometimes detectable on some thicker, twelve-sided crystals (Figure 3). SEM analysis revealed that a sample population often included crystals at different stages of maturity (i.e. having immature four-sided forms, intermediate twelve-sided or 'winged' forms, and mature six-eight sided or faceted forms) (Figure 4). It was also noted that the terminations of some Type III raphides were finely serrated, as shown in Figure 5, but this feature was both rare and inconsistent within these samples. No other morphological features were observed on raphides from this group which could be used to further differentiate taxa.

Type I raphides were only observed in the Pandanaceae, and were present in both species analysed. These crystals had the same simple symmetrical morphology as the Type III forms when viewed by light microscopy. It was only possible to determine sectional shape with SEM (see examples in Figure 6).

All members of the Araceae produced Type IV raphides that differed considerably in terms of their morphologies and assemblage compositions (see Figure 7 to Figure 9 for examples from each species). Features differentiating aroid raphides from one another included whether or not the bridge and/or grooves were visible by light microscopy (which was generally directly related to overall raphide size), the location (centred/offset) and length (short/long compared to overall crystal length) of the bridge, and the shape of the short termination (continuous-wedge/protrudingwedge/tapered) (see Figure 10). The short wedge-shaped termination on asymmetrical crystals was either continuous (SWC) or protruding (SWP), while protruding forms had either square (SWP1) or inflected (SWP2) shoulders depending on crystal orientation. Barbs were very rarely observed and appear therefore to have little taxonomic value (cf. Figure 8b). The configuration of these morphological characteristics was generally consistent within each species regardless of the plant 

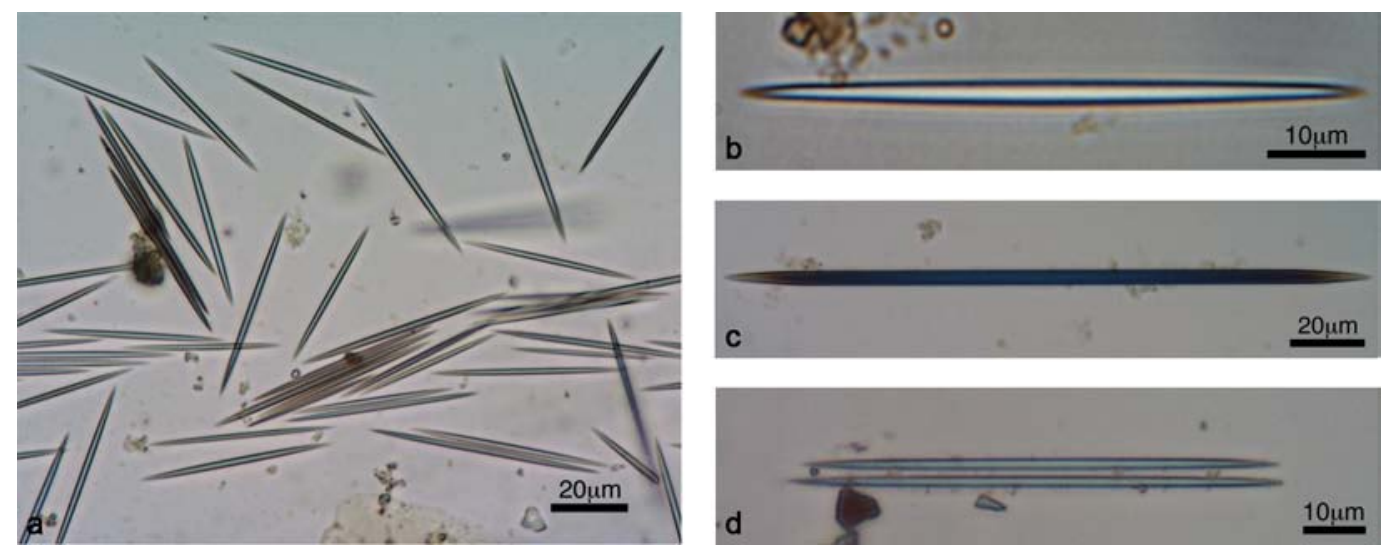

Figure 2. Light micrograph examples of Type III raphides from various species: (a) Cordyline terminalis (leaf); (b) Dioscorea bulbifera (bulbil); (c) Heliconia indica (corm); and (d) Musa maclayi (bract) [all images transmitted light; (d) part-polarised].
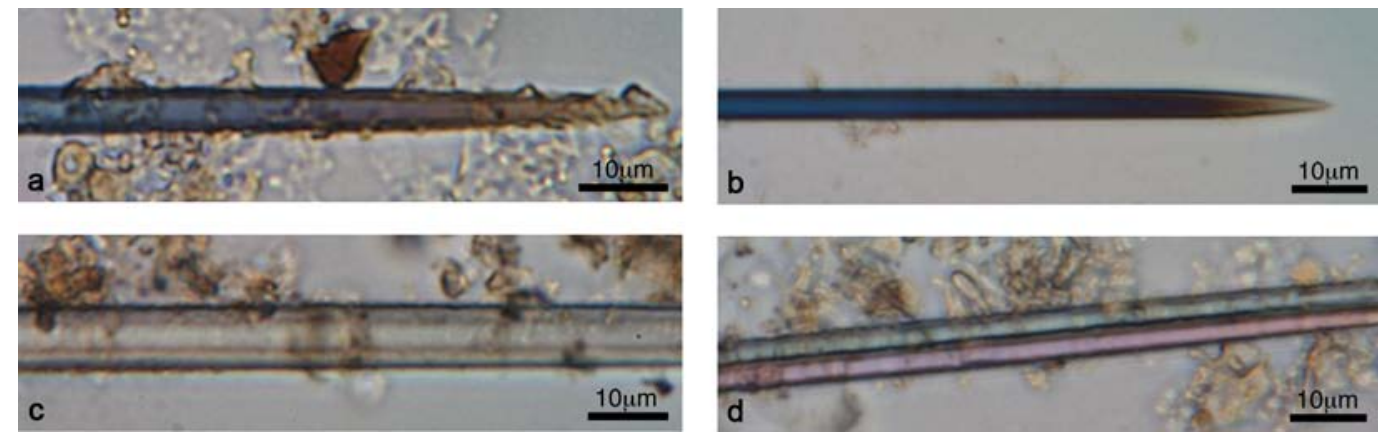

Figure 3. Examples of 'wings' visible on some thicker Type III raphides with light microscopy: (a) Caryota rumphiana (leaf), (b) Heliconia indica (corm), (c) Caryota mitis (fruit); and (d) Musa acuminata (petiole) [all images transmitted light].

part studied, although whether or not the bridge and grooves were visible by light microscopy tended to be more variable. The visibility of these features appeared to correspond with raphide size, as they were generally less distinctive on thinner (and usually shorter) raphides.

From these observations, a morphological key describing raphides typical of each aroid species was developed and is summarised Table 3. Using this key, for example, Alocasia macrorrhiza raphides may be differentiated from the other aroid species studied by their bridge, which is visible with light microscopy and relatively short compared to overall crystal length, as well as the shape of the short, wedge-shaped termination. By comparison, Cyrtosperma spp. (Figure 9a-c) and Xanthosoma sagittifolium (Figure 9d-e) have much longer bridges, while the bridge of Colocasia esculenta raphides (Figure 9f-g) is very rarely visible and not nearly as pronounced as that of Alocasia. Amorphophallus spp. typically had offset bridges and very distinctive protruding terminations, including some with inflected shoulders (Figure 8).

In some cases, the large size range within a single organ created the impression that more than one morphometric type existed within a single population. This phenomenon was observed in Alocasia macrorrhiza (flower), Amorphophallus blumei (leaf and petiole), Colocasia esculenta (petiole and root) and Xanthosoma sagittifolum (stem) (each morphometric type is described separately for these samples in Table 4). Scatterplots between the lengths and widths of these samples revealed that the populations were more or less continuously distributed along these variables and therefore are unlikely to represent discrete 'types'. The only exception was Amorphophallus blumei, in which bimodal populations with significantly different morphological features were present in both the leaf and petiole. The taxonomic implications of this variation are discussed later. 

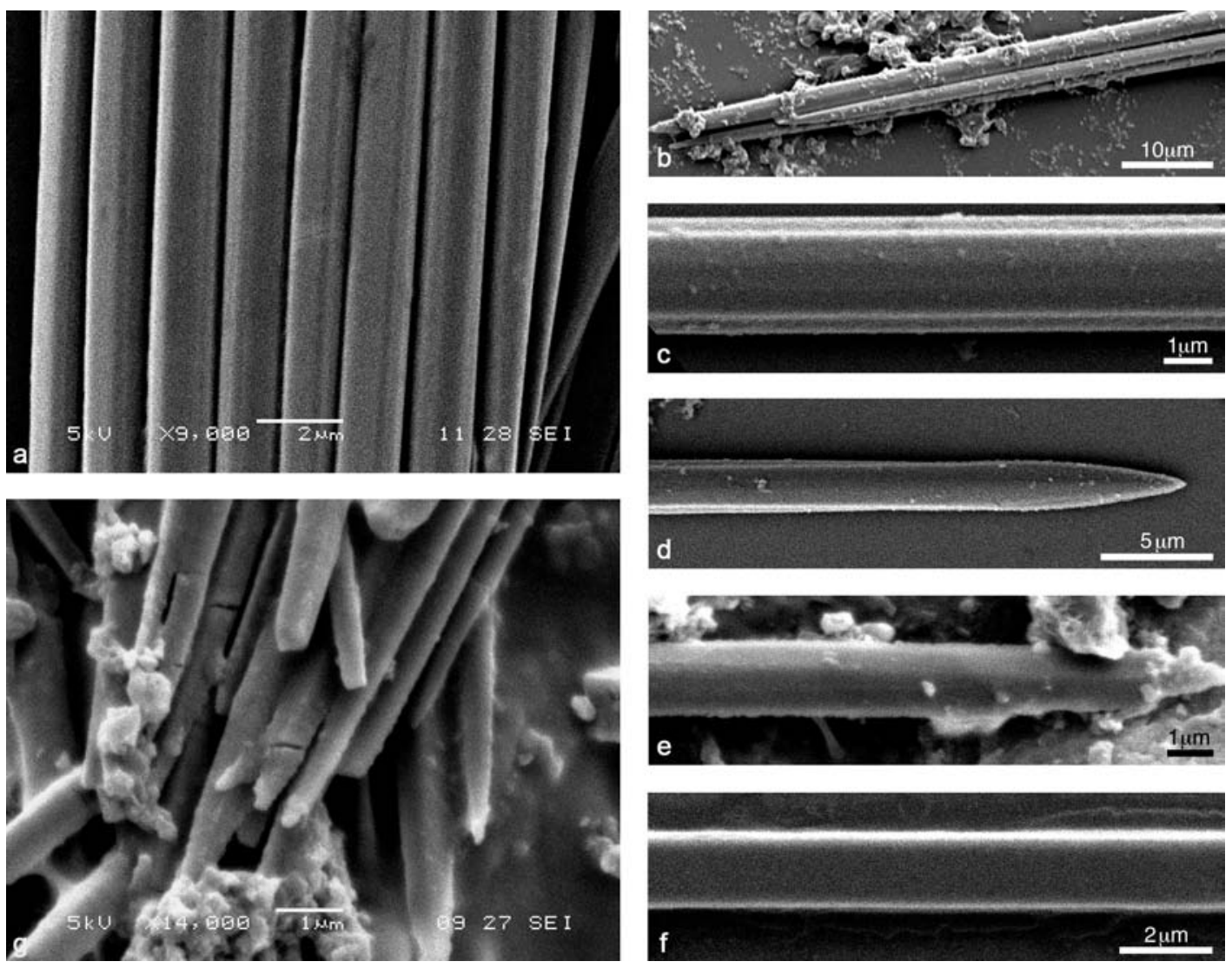

Figure 4. Examples of Type III raphides showing features observed during SEM: (a-b) mature facetted forms, (c) intermediate 'winged' forms, (d) transition to 6-sides at termination of a mature raphide, (e) transition from 12- to 6-sides at termination of an intermediate raphide, and (f-g) immature raphides with square sections [(a, g) Cordyline terminalis, (b) Musa maclayi, (d, f) Caryota rumphiana, (c, e) Dioscorea bulbifera].
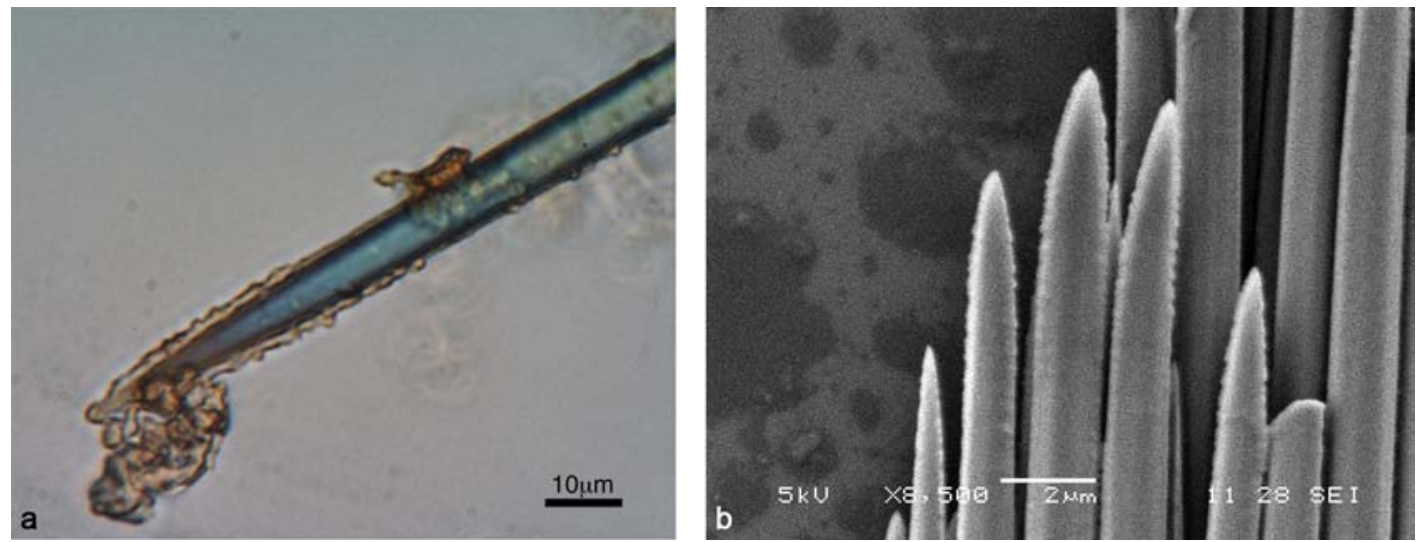

Figure 5. Examples of finely serrated terminations present on some Type III raphides [(a) Caryota mitis, transmitted light; (b) Cordyline terminalis].

\section{Whisker raphides}

Frequency and maximum length data for whisker raphides are summarised in Table 5. This raphide type was mainly observed in members of the Araceae (examples shown in Figure 11a, c) but was also present in several non-aroid taxa (Figure 11b, d). Curved whisker raphides (Figure 11c) were only observed in the Araceae, albeit rarely. Not all aroids contained whisker raphides - for example, they were completely absent from both species of Cyrtosperma, as well as Xanthosoma sagittifolium - but where present they were typically very abundant. Whisker 

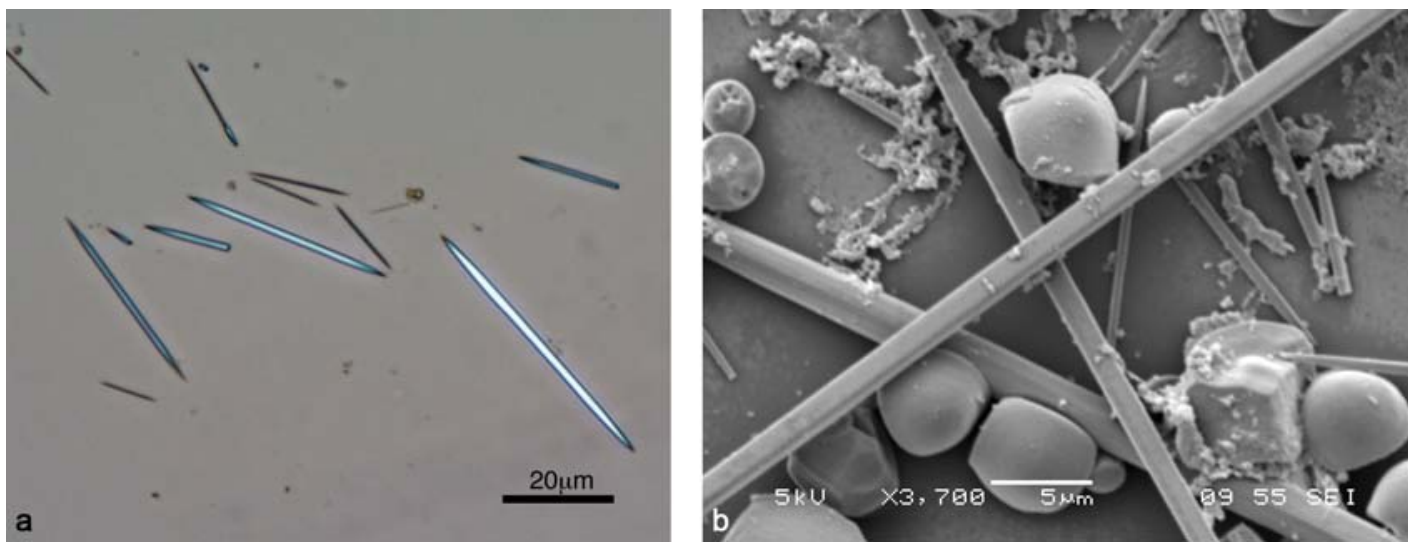

Figure 6. Type I raphides from Pandanus dubius [(a) part-polarised transmitted light; (b) SEM].
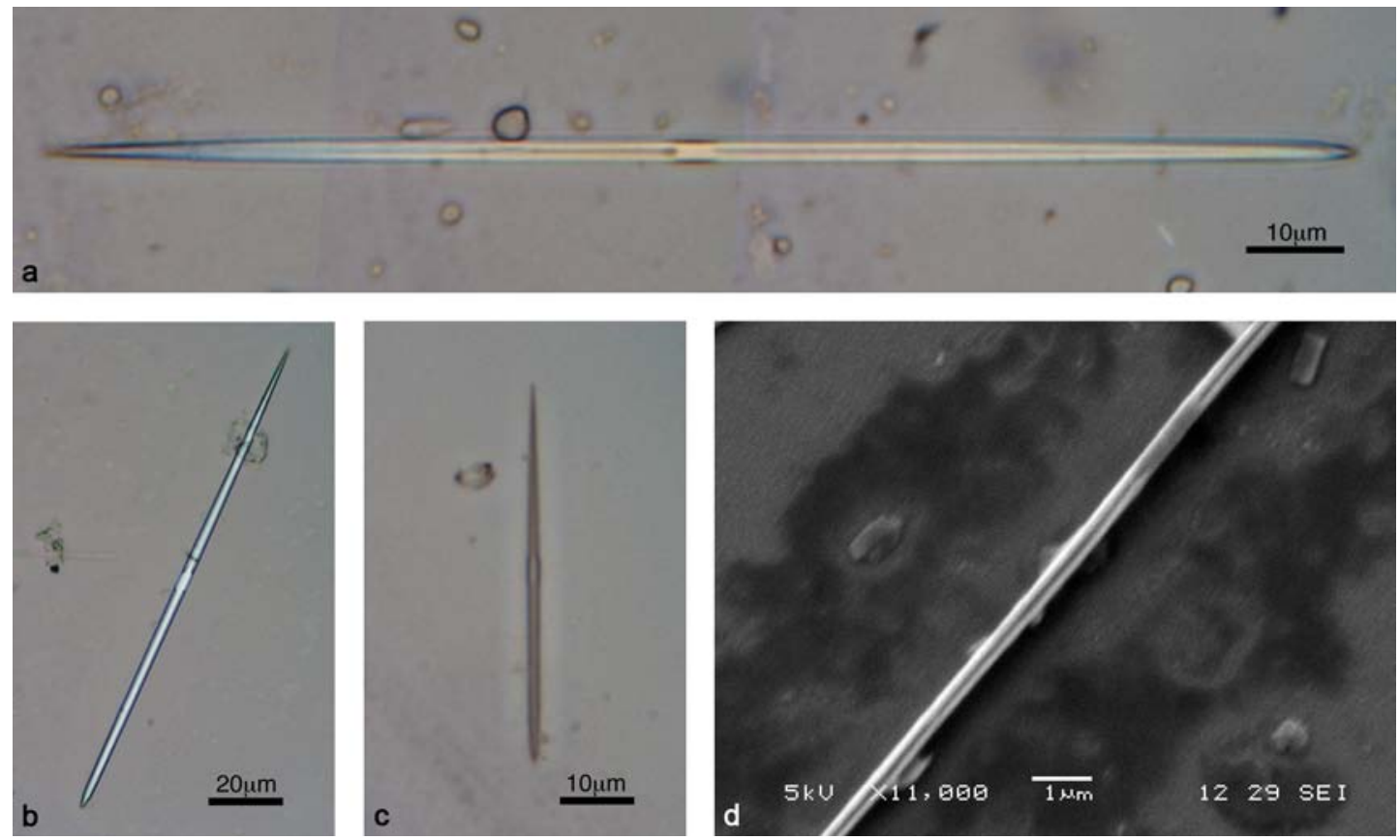

Figure 7. Examples of Alocasia macrorrhiza raphides showing: (a) grooves on larger types; (a-c) short, central bridge; and (d) whisker type with bridge and grooves which are visible only with SEM [(a-c) transmitted light; (a-b) part-polarised].

types were generally less frequent in non-aroid taxa and had shorter maximum lengths. They were the only raphide type present in the fruit of Musa maclayi, in which they were very abundant. It was found that maximum whisker length often exceeded that of non-whisker types, suggesting that they do not represent an immature crystal form as suggested by Loy et al. (1992:900). SEM analysis of whiskers from Alocasia macrorrhiza also revealed that they have mature Type IV morphologies, as shown in Figure 7d.

\section{Results of statistical analyses}

Box-and-whisker plots summarising the main descriptive statistics for raphide length are shown in Figure 12 and Figure 13 for the Type I/III and Type IV groups respectively. These plots indicate that although there is considerable overlap in the spread of raphide lengths, both within and between species, mean lengths are more varied. Some aroids (Alocasia macrorrhiza and Amorphophallus spp.) produce raphides with much greater size ranges, as does Caryota mitis (fruit, root and seed) in the Type I/III group. Detailed summaries of the descriptive statistics for both length and width, as well as estimates of raphide abundance within each plant, are presented in Table 6. 

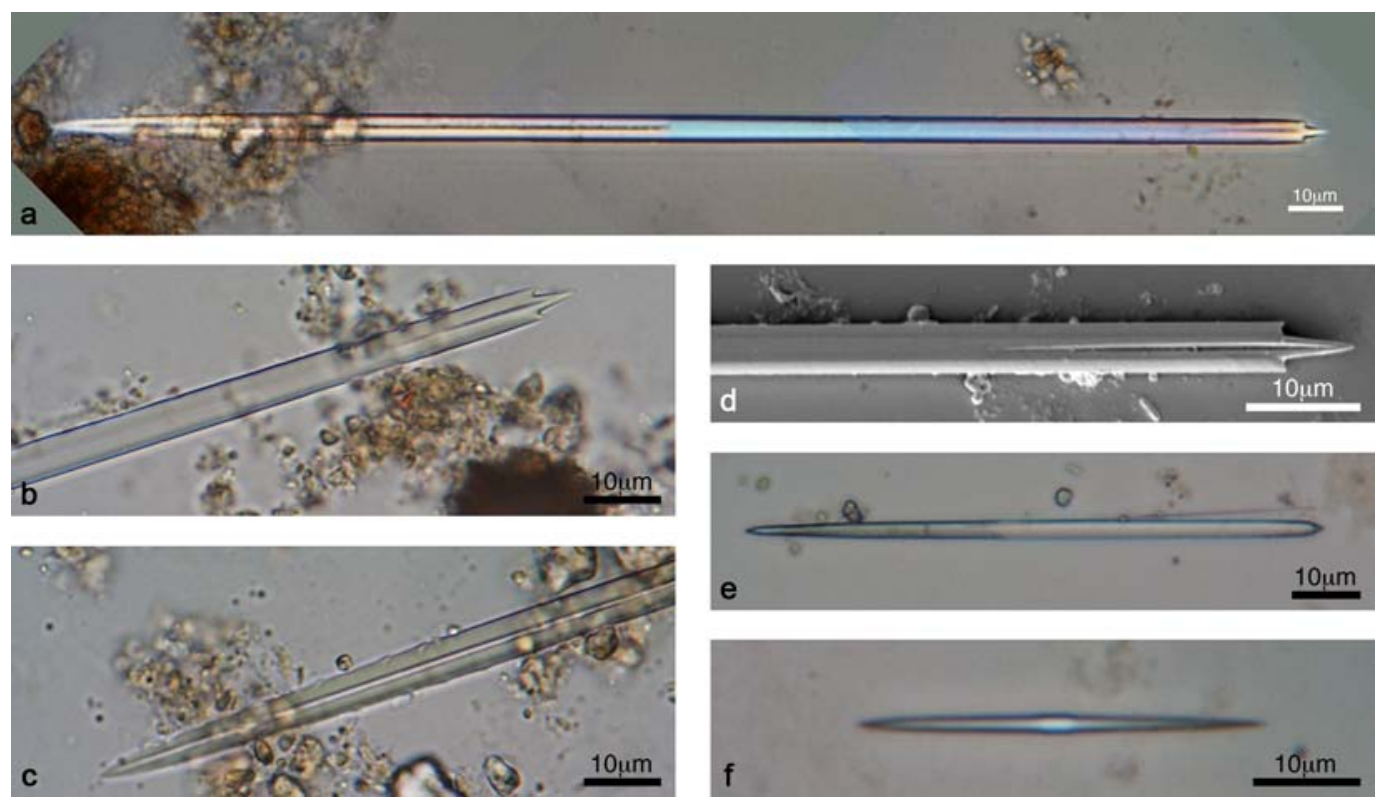

Figure 8. Examples of Amorphophallus blumei raphides showing morphological features visible on different sized crystals: (a-d) protruding wedge-shaped end, (a, e) long offset bridge and (a-d) grooves visible on larger types; (b-c) barbs visible on very large types; and (f) smaller, more symmetrical types with short, central bridges [all images except (c) transmitted light; (a) and (e) part-polarised].
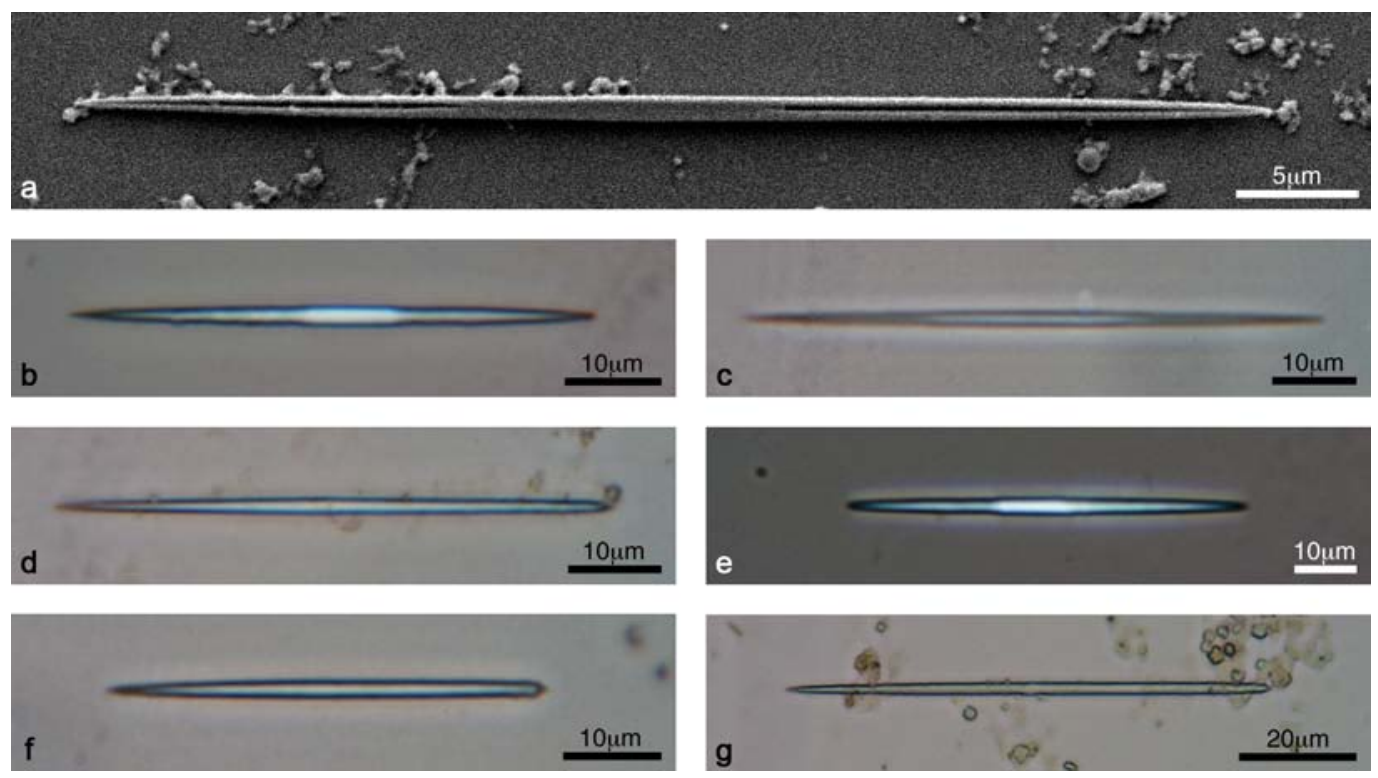

Figure 9. SEM and light microscopy examples of aroid raphides: (a-b) Cyrtosperma johnstonii and (c) Cyrtosperma chamissonis raphides showing similar symmetrical forms with a relatively long, centred bridge; (d-e) Xanthosoma sagittifolium raphides showing (d) asymmetrical type from the petiole with one short wedge-shaped end and lack of visible bridge, and (e) symmetrical type from the stem with visible long, centred bridge; and (f-g) examples of Colocasia esculenta raphides, showing asymmetrical form and lack of visible bridge or groove in light microscopy [all images except (a) transmitted light; (b, e) partpolarised].

The multivariate analyses revealed that there are highly significant differences $(\mathrm{p}<0.001)$ between mean raphide sizes, both within individual species (Table 7) and between organs from different species within each morphological group (Table 8 ). The only exception was Pandanus dubius, $\mathrm{F}(4,294)=1.20, \mathrm{p}=0.312$, whose organ means cluster tightly around 40-47 $\mu \mathrm{m}$ (see 


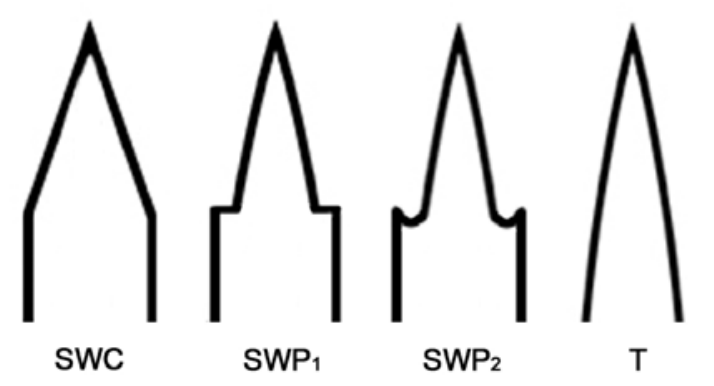

Figure 10. Diagram of termination types observed on Type IV raphides. The short wedge-shaped termination on asymmetrical crystals was either continuous (SWC) or protruding (SWP). Protruding forms have either square (SWP1) or inflected (SWP2) shoulders depending on crystal orientation. Terminations on symmetrical crystals are tapered $(\mathrm{T})$.

Figure 12). The follow-up ANOVA tests indicated that variability in raphide size is generally significant for both length and width rather than just one of the two, although in some cases width was insignificant (see Table 7 and Table 8 for these results).

Minimum sample size calculations (Table 6) indicated that a sample of 50 raphides was adequate in about $50 \%$ of cases. The average minimum sample size required was 96 , but this figure is inflated significantly by a few cases $(n=15)$ where much larger samples of between $\sim 250$ and 1000 were required. The particularly high $n_{\min }$ values calculated for Amorphophallus blumei leaf $\left(n_{\min }=797\right)$ and petiole $\left(n_{\min }=986\right)$ are most likely caused by the wide size range and bimodal distributions detected within these samples. If $n_{\min }$ values greater than 250 are excluded from the calculation, the average minimum sample size required is 56 . The sample of 50 raphides analysed for each organ is therefore considered generally adequate for the purposes of this study.

\section{DISCUSSION}

The results of this study indicate that raphide morphology varies little across all taxa analysed aside from the Araceae, which produce a diagnostic form not currently observed in any other economically important Pacific family. Raphide form also differs significantly between aroid genera, which offers some scope for determining species of origin in contexts where only a limited range of aroid taxa are likely to occur. Size on the other hand varies considerably both within and between most species for all groups analysed. The high degree of intra-species heterogeneity in raphide size is a major limitation on using this variable for taxonomic studies.

\section{Morphological variation}

The most taxonomically meaningful raphide forms were observed within the Araceae which, as predicted from the literature review, was the only taxon found to produce Type IV raphides.

Table 3. General summary of key morphological features of raphides from the Araceae visible by light microscopy

\begin{tabular}{|l|l|l|l|}
\hline Species & Bridge (if visible) & Grooves & $\begin{array}{l}\text { Shape of the short } \\
\text { termination }\end{array}$ \\
\hline Alocasia macrorrhiza & Short, centred & Visible on thicker types & Continuous wedge \\
\hline Amorphophallus blumei & $\begin{array}{l}\text { Short, centred } \\
\text { thinner types); long, } \\
\text { offset (thicker types) }\end{array}$ & Visible on thicker types & $\begin{array}{l}\text { Protruding wedge (thicker } \\
\text { types); continuous wedge } \\
\text { or tapered (thinner types) }\end{array}$ \\
\hline $\begin{array}{l}\text { Amorphophallus } \\
\text { campanulatus }\end{array}$ & $\begin{array}{l}\text { Long, offset; rarely } \\
\text { centred }\end{array}$ & Visible on thicker types & Protruding wedge \\
\hline Colocasia esculenta & Not/rarely visible & Not visible & Continuous wedge \\
\hline $\begin{array}{l}\text { Cyrtosperma } \\
\text { chamissonis }\end{array}$ & $\begin{array}{l}\text { Rarely visible; long, } \\
\text { centred }\end{array}$ & Not visible & Tapered \\
\hline Cyrtosperma johnstonii & Long, centred & Not visible & Tapered \\
\hline $\begin{array}{l}\text { Xanthosoma } \\
\text { sagittifollium }\end{array}$ & Long, centred & Not visible & $\begin{array}{l}\text { Continuous wedge or } \\
\text { tapered }\end{array}$ \\
\hline
\end{tabular}


Table 4. Summary of morphometric features of raphides from the Araceae observed during light microscopy

\begin{tabular}{|c|c|c|c|c|c|c|c|c|c|}
\hline \multirow[b]{2}{*}{ Species } & \multirow[b]{2}{*}{ Organ } & \multicolumn{2}{|c|}{$\begin{array}{l}\text { Whisker } \\
\text { raphides }\end{array}$} & \multicolumn{6}{|c|}{ Non-Whisker raphides } \\
\hline & & Freq $^{a}$ & $\begin{array}{r}\text { Max } \\
\mathrm{L}^{\mathrm{b}} \\
(\mu \mathrm{m}) \\
\end{array}$ & Freq $^{a}$ & $L^{c}(\mu \mathrm{m})$ & $\begin{array}{r}W^{d} \\
(\mu \mathrm{m})\end{array}$ & Bridge $^{e}$ & $G_{r v}^{f}$ & Term $^{g}$ \\
\hline \multirow{6}{*}{$\begin{array}{l}\text { Alocasia } \\
\text { macrorrhiza }\end{array}$} & \multirow[t]{2}{*}{ Flower } & \multirow[t]{2}{*}{$A$} & \multirow[t]{2}{*}{-} & $\mathrm{C}$ & $35-95$ & 1.0 & NV & NV & Wk Assym \\
\hline & & & & $\mathrm{R}$ & $60-115$ & $1.5-2.5$ & $\mathrm{RV}, \mathrm{S}, \mathrm{C}$ & NV & $\mathrm{SWC}+\mathrm{T}$ \\
\hline & Leaf & $A b$ & 100 & $\mathrm{R}$ & $45-200$ & $1.5-3.5$ & $\mathrm{~V}, \mathrm{~S}, \mathrm{C}$ & $\mathrm{V}$ & $S W C+T$ \\
\hline & Petiole & Vab & 100 & $\mathrm{Vr}$ & $\begin{array}{l}150- \\
240\end{array}$ & $3.0-5.0$ & V, S, C & $\mathrm{V}$ & $S W C+T$ \\
\hline & Root & Vab & 105 & $\mathrm{R}$ & $\begin{array}{l}170- \\
280\end{array}$ & $3.0-5.5$ & V, S, C & $\mathrm{V}$ & $S W C+T$ \\
\hline & Stem & Vab & 95 & $\mathrm{Vr}$ & $\begin{array}{l}255- \\
270\end{array}$ & $3.5-4.5$ & V, S, C & $\mathrm{V}$ & $S W C+T$ \\
\hline \multirow{7}{*}{$\begin{array}{l}\text { Amorphophallus } \\
\text { blumei }\end{array}$} & Bulbil & Vab & 70 & $\mathrm{C}$ & $85-225$ & $1.5-5.0$ & $\mathrm{~V}, \mathrm{~L}, \mathrm{O}$ & $\mathrm{V}$ & $S W P+T$ \\
\hline & \multirow[t]{2}{*}{ Leaf } & \multirow[t]{2}{*}{ Vab } & \multirow[t]{2}{*}{75} & C & $20-90$ & $1.0-1.5$ & Vx, S, C & NV & $S W C+T$ \\
\hline & & & & $\mathrm{R}$ & $\begin{array}{l}150- \\
290\end{array}$ & $2.5-6.0$ & V, L, O & $\mathrm{V}$ & $\mathrm{SWP}+\mathrm{T}$ \\
\hline & \multirow[t]{2}{*}{ Petiole } & \multirow[t]{2}{*}{$A b$} & \multirow[t]{2}{*}{75} & C & $20-100$ & 1.0 & Vx, S, C & $\mathrm{NV}$ & $T$ \\
\hline & & & & C & $\begin{array}{l}150- \\
250\end{array}$ & $3.0-4.5$ & $\mathrm{~V}, \mathrm{~L}, \mathrm{O}$ & $\mathrm{V}$ & $S W P+T$ \\
\hline & Root & $A b$ & 65 & $\mathrm{R}$ & $\begin{array}{l}130- \\
260\end{array}$ & $2.0-5.5$ & V, L, O & $\mathrm{V}$ & $\mathrm{SWP}+\mathrm{T}$ \\
\hline & Tuber & $A b$ & 85 & $\mathrm{C}$ & $\begin{array}{l}140- \\
265\end{array}$ & $2.0-6.0$ & V, L, O & V & $S W P+T$ \\
\hline $\begin{array}{l}\text { Amorphophallus } \\
\text { campanulatus }\end{array}$ & Tuber & Vab & 80 & $\mathrm{C}$ & $\begin{array}{l}110- \\
170\end{array}$ & $2.0-3.5$ & $\mathrm{~V}, \mathrm{~L}, \mathrm{O} / \mathrm{C}$ & $\mathrm{V}$ & $S W P+T$ \\
\hline \multirow{6}{*}{$\begin{array}{l}\text { Colocasia } \\
\text { esculenta }\end{array}$} & Leaf & C & 120 & $\mathrm{R}$ & $30-55$ & $1.0-2.0$ & NV & NV & $S W C+T$ \\
\hline & \multirow[t]{2}{*}{ Petiole } & \multirow[t]{2}{*}{$\mathrm{Ab}$} & \multirow[t]{2}{*}{100} & $\mathrm{R}$ & $20-55$ & 1.0 & NV & NV & Wk Assym \\
\hline & & & & $\mathrm{R}$ & $60-80$ & $1.5-2.0$ & $\mathrm{RV}, \mathrm{S}, \mathrm{C}$ & NV & $\mathrm{SWC} / \mathrm{P}+\mathrm{T}$ \\
\hline & \multirow[t]{2}{*}{ Root } & \multirow[t]{2}{*}{ A } & \multirow[t]{2}{*}{-} & C & $15-40$ & 1.0 & NV & NV & Wk Assym \\
\hline & & & & $\mathrm{R}$ & $60-90$ & $1.5-2.0$ & NV & NV & $S W C+T$ \\
\hline & Tuber & $\mathrm{R}$ & 85 & C & $50-95$ & $1.0-1.5$ & NV & NV & $\mathrm{SWC}+\mathrm{T}$ \\
\hline $\begin{array}{l}\text { Cyrtosperma } \\
\text { chamissonis }\end{array}$ & Tuber & $A$ & - & $\mathrm{C}$ & $45-70$ & $1.0-1.5$ & RV, L. C & NV & $\mathrm{T}$ \\
\hline \multirow{5}{*}{$\begin{array}{l}\text { Cyrtosperma } \\
\text { johnstonii }\end{array}$} & Flower & A & - & $A b$ & $40-80$ & $1.0-1.5$ & RV, L. C & NV & $\mathrm{T}$ \\
\hline & Leaf & $A$ & - & $\mathrm{Ab}$ & $25-60$ & $1.0-1.5$ & Vx, L, C & NV & $\mathrm{T}$ \\
\hline & Petiole & A & - & C & $35-65$ & $1.0-1.5$ & $V x, L, C$ & NV & $\mathrm{T}$ \\
\hline & Root & $\mathrm{A}$ & - & $\mathrm{C}$ & $20-50$ & 1.0 & Vx, L, C & NV & $\mathrm{T}$ \\
\hline & Tuber & A & - & $\mathrm{C}$ & $35-65$ & $1.0-2.0$ & Vx, L, C & NV & $\mathrm{T}$ \\
\hline \multirow{5}{*}{$\begin{array}{l}\text { Xanthosoma } \\
\text { sagitifolium }\end{array}$} & Leaf & $\mathrm{A}$ & - & $\mathrm{Vr}$ & $30-70$ & 1.0 & NV & NV & $S W C+T$ \\
\hline & Petiole & A & - & C & $30-65$ & $1.0-1.5$ & NV & $\mathrm{NV}$ & $S W C+T$ \\
\hline & Root & A & - & $\mathrm{C}$ & $30-65$ & $1.0-2.0$ & $V x, L, C$ & NV & $\mathrm{T}$ \\
\hline & \multirow[t]{2}{*}{ Stem } & \multirow[t]{2}{*}{$A$} & - & C & $25-40$ & 1.0 & NV & NV & $\mathrm{T}$ \\
\hline & & & & $\mathrm{Vr}$ & $50-70$ & $1.5-2.5$ & $V x, L, C$ & NV & $\mathrm{T}$ \\
\hline $\begin{array}{l}\text { a Frequency (Fre } \\
{ }^{\text {b } M a x . ~ L-~ m a x i m ~} \\
{ }^{c} \text { L - length (rang } \\
{ }^{d} \text { W - width (rang } \\
\text { e Bridge key: visi } \\
\text { polarised light, V }\end{array}$ & $\begin{array}{l}\text { y with I } \\
\text { isible; Ie }\end{array}$ & $\begin{array}{l}\text { t micro } \\
\text { th: } L-\end{array}$ & $\begin{array}{l}\text { copy: } \\
\text { ng, s }\end{array}$ & $\begin{array}{l}\text { V - not } \\
\text { short; }\end{array}$ & $\begin{array}{l}\text { isible, R } \\
\text { sition: C }\end{array}$ & $\begin{array}{l}\text { - rarely } \\
\text { - centere }\end{array}$ & $\begin{array}{l}\text { visible, Vx } \\
\text { O-offse }\end{array}$ & mainly & isible in cross \\
\hline${ }^{f}$ Groove (Grv) vis & ility key: & - visibl & NV - & ot visib & & & & & \\
\hline $\begin{array}{l}\text { g Termination ( } \mathrm{Te} \\
\text { protruding short } \mathrm{v}\end{array}$ & $\begin{array}{l}\text { type } \\
\text { ge; } T-\end{array}$ & $\begin{array}{l}\text { Wk A } \\
\text { ered }\end{array}$ & ssym & weakly & ymmet & al; SWC & contin & sh & edge; SWP - \\
\hline
\end{tabular}


Table 5. Summary of frequency (Freq) and maximum length (Max. length) of non-aroid whisker raphides for each species where present

\begin{tabular}{|l|l|l|c|c|}
\hline \multirow{2}{*}{ Family } & Species & Organ & Freq $^{\text {a }}$ & $\begin{array}{c}\text { Max. } \\
\text { length } \\
(\boldsymbol{\mu m})\end{array}$ \\
\hline Dioscoreaceae & Dioscorea hispida & Leaf & $\mathrm{Ab}$ & 10 \\
\hline Heliconiaceae & Heliconia indica & Root & $\mathrm{R}$ & 45 \\
\hline Musaceae & Musa maclayi & Bract & $\mathrm{C}-\mathrm{Ab}$ & 60 \\
\cline { 3 - 5 } & & Leaf & $\mathrm{C}$ & 65 \\
\cline { 3 - 5 } & Fruit & Vab & 70 \\
\hline \multirow{2}{*}{ Pandanaceae } & \multirow{2}{*}{ Pandanus dubius } & Root & $\mathrm{Ab}-\mathrm{Vab}$ & 50 \\
\cline { 3 - 5 } & Wood & $\mathrm{C}-\mathrm{Ab}$ & 40 \\
\cline { 3 - 5 } & Pandanus tectorius & Root & $\mathrm{C}$ & 65 \\
\cline { 3 - 5 } & Wood & $\mathrm{Ab}$ & 50 \\
\hline \multirow{2}{*}{$\begin{array}{l}\text { a - Frequency } \\
\text { abundant }\end{array}$} & key: R - rare; C - common; Ab - abundant; Vab - very \\
\hline
\end{tabular}

Table 6. Summary of descriptive statistics for raphide length $(L)$ and width $(W)$, showing sample sizes (n), minimum adequate sample sizes $\left(n_{\text {min }}\right)$, ranges, minimum (Min) and maximum (Max) values, means, standard deviations (St dev), and estimated frequency (Freq) of non-whisker types

\begin{tabular}{|c|c|c|c|c|c|c|c|c|c|c|}
\hline Family: Species & Organ & $\begin{array}{l}\mathrm{L} / \mathrm{W} \\
(\mu \mathrm{m})\end{array}$ & $n$ & $n_{\min }^{a}$ & Range & $\begin{array}{l}\text { Min } \\
(\mu \mathrm{m})\end{array}$ & $\begin{array}{l}\text { Max } \\
(\mu \mathrm{m})\end{array}$ & $\begin{array}{l}\text { Mean }^{b} \\
(\mu \mathrm{m})\end{array}$ & $\begin{array}{c}\text { St } \\
\mathrm{dev}^{\mathrm{b}}\end{array}$ & Freq $^{c}$ \\
\hline \multirow{10}{*}{$\begin{array}{l}\text { Araceae: } \\
\text { Alocasia } \\
\text { macrorrhiza }\end{array}$} & \multirow[t]{2}{*}{ Flower } & L & 50 & 51 & 76 & 39 & 115 & 69.5 & 15.0 & \multirow{2}{*}{$\mathrm{R}-\mathrm{C}$} \\
\hline & & W & 50 & 73 & 1.5 & 1 & 2.5 & 1.0 & 0.5 & \\
\hline & \multirow[t]{2}{*}{ Leaf } & L & 50 & 78 & 149 & 47 & 196 & 132.0 & 35.5 & \multirow{2}{*}{$\mathrm{R}$} \\
\hline & & W & 50 & 59 & 2 & 1.5 & 3.5 & 2.5 & 0.5 & \\
\hline & \multirow[t]{2}{*}{ Petiole } & $\mathrm{L}$ & 5 & 27 & 78 & 154 & 232 & 186.0 & 29.0 & \multirow{2}{*}{$\mathrm{Vr}$} \\
\hline & & $\mathrm{W}$ & 5 & 75 & 2 & 3 & 5 & 3.5 & 1.0 & \\
\hline & \multirow[t]{2}{*}{ Root } & $L$ & 50 & 13 & 110 & 170 & 280 & 242.5 & 27.0 & \multirow{2}{*}{$\mathrm{R}$} \\
\hline & & W & 50 & 23 & 2.5 & 3 & 5.5 & 4.5 & 0.5 & \\
\hline & \multirow[t]{2}{*}{ Stem } & $\mathrm{L}$ & 4 & 1 & 15 & 255 & 270 & 264.0 & 6.5 & \multirow{2}{*}{$\mathrm{Vr}$} \\
\hline & & W & 4 & 15 & 1 & 3.5 & 4.5 & 4.0 & 0.5 & \\
\hline \multirow{10}{*}{$\begin{array}{l}\text { Amorphophallus } \\
\text { blumei }\end{array}$} & \multirow[t]{2}{*}{ Bulbil } & $L$ & 50 & 63 & 139 & 85 & 224 & 141.5 & 34.0 & \multirow{2}{*}{$\mathrm{R}-\mathrm{C}$} \\
\hline & & W & 50 & 68 & 3.5 & 1.5 & 5 & 3.0 & 0.5 & \\
\hline & \multirow[t]{2}{*}{ Leaf } & $L$ & 50 & 986 & 272 & 18 & 290 & 93.0 & 88.5 & \multirow{2}{*}{ C } \\
\hline & & W & 50 & 636 & 5 & 1 & 6 & 2.0 & 1.5 & \\
\hline & \multirow[t]{2}{*}{ Petiole } & $\mathrm{L}$ & 50 & 797 & 219 & 21 & 240 & 92.5 & 79.0 & \multirow{2}{*}{ C } \\
\hline & & W & 50 & 473 & 3.5 & 1 & 4.5 & 2.0 & 1.5 & \\
\hline & \multirow[t]{2}{*}{ Root } & L & 10 & 43 & 104 & 150 & 254 & 188.0 & 37.5 & \multirow{2}{*}{$\mathrm{R}$} \\
\hline & & W & 10 & 106 & 3.5 & 2 & 5.5 & 3.5 & 1.0 & \\
\hline & \multirow[t]{2}{*}{ Tuber } & $L$ & 50 & 22 & 123 & 142 & 265 & 186.0 & 27.0 & \multirow{2}{*}{ C } \\
\hline & & W & 50 & 43 & 4 & 2 & 6 & 4.0 & 1.0 & \\
\hline \multirow{2}{*}{$\begin{array}{l}\text { Amorphophallus } \\
\text { campanulatus }\end{array}$} & \multirow[t]{2}{*}{ Tuber } & L & 50 & 8 & 60 & 108 & 168 & 149.0 & 12.5 & \multirow{2}{*}{ C } \\
\hline & & W & 50 & 30 & 1.5 & 2 & 3.5 & 3.0 & 0.5 & \\
\hline
\end{tabular}




\begin{tabular}{|c|c|c|c|c|c|c|c|c|c|c|}
\hline Family: Species & Organ & $\begin{array}{l}\mathrm{L} / \mathrm{W} \\
(\mu \mathrm{m})\end{array}$ & $n$ & $n_{\text {min }}{ }^{a}$ & Range & $\begin{array}{c}\text { Min } \\
(\mu \mathrm{m})\end{array}$ & $\begin{array}{l}\text { Max } \\
(\mu \mathrm{m})\end{array}$ & $\begin{array}{c}\text { Mean }^{\mathrm{b}} \\
(\mu \mathrm{m})\end{array}$ & $\begin{array}{c}\text { St } \\
\operatorname{dev}^{b}\end{array}$ & Freq $^{c}$ \\
\hline \multirow{8}{*}{$\begin{array}{l}\text { Colocasia } \\
\text { esculenta }\end{array}$} & \multirow[t]{2}{*}{ Leaf } & $\mathrm{L}$ & 50 & 11 & 25 & 30 & 55 & 43.5 & 4.5 & \multirow{2}{*}{$\mathrm{R}$} \\
\hline & & W & 50 & 47 & 1 & 1 & 2 & 1.0 & 0.5 & \\
\hline & \multirow[t]{2}{*}{ Petiole } & $\mathrm{L}$ & 50 & 166 & 58 & 20 & 78 & 53.5 & 202.0 & \multirow{2}{*}{$\mathrm{R}$} \\
\hline & & W & 50 & 95 & 1 & 1 & 2 & 1.5 & 0.5 & \\
\hline & \multirow[t]{2}{*}{ Root } & $\mathrm{L}$ & 50 & 281 & 74 & 16 & 90 & 32.0 & 16.0 & \multirow{2}{*}{$\mathrm{R}-\mathrm{C}$} \\
\hline & & W & 50 & 36 & 1 & 1 & 2 & 1.0 & 0.5 & \\
\hline & \multirow[t]{2}{*}{ Tuber } & $\mathrm{L}$ & 50 & 9 & 42 & 52 & 94 & 78.5 & 7.0 & \multirow{2}{*}{ C } \\
\hline & & W & 50 & 38 & 1 & 1 & 2 & 1.5 & 0.5 & \\
\hline \multirow{2}{*}{$\begin{array}{l}\text { Cyrtosperma } \\
\text { chamissonis }\end{array}$} & \multirow[t]{2}{*}{ Tuber } & $\mathrm{L}$ & 50 & 13 & 25 & 45 & 70 & 59.0 & 6.5 & \multirow{2}{*}{ C } \\
\hline & & W & 50 & 52 & 1 & 0.5 & 1.5 & 1.0 & 0.5 & \\
\hline \multirow{10}{*}{$\begin{array}{l}\text { Cyrtosperma } \\
\text { johnstonii }\end{array}$} & \multirow[t]{2}{*}{ Flower } & $\mathrm{L}$ & 50 & 20 & 40 & 40 & 80 & 55.5 & 7.5 & \multirow{2}{*}{$A b$} \\
\hline & & W & 50 & 34 & 0.5 & 1 & 1.5 & 1.0 & 0.0 & \\
\hline & Leaf & $\mathrm{L}$ & 50 & 44 & 32 & 25 & 57 & 43.0 & 8.5 & $\Delta h$ \\
\hline & & W & 50 & 10 & 0.5 & 1 & 1.5 & 1.0 & 0.0 & AD \\
\hline & Petiole & $\mathrm{L}$ & 50 & 10 & 30 & 36 & 66 & 50.0 & 5.0 & C \\
\hline & & W & 50 & 38 & 0.5 & 1 & 1.5 & 1.0 & 0.0 & c \\
\hline & Root & $\mathrm{L}$ & 50 & 31 & 28 & 20 & 48 & 33.0 & 5.5 & C \\
\hline & & W & 50 & 1 & 0 & 1 & 1 & 1.0 & 0.0 & $c$ \\
\hline & Tuber & $\mathrm{L}$ & 50 & 16 & 30 & 35 & 65 & 44.0 & 5.5 & C \\
\hline & & W & 50 & 46 & 1 & 1 & 2 & 1.0 & 0.0 & C \\
\hline Xanthosoma & Leaf & $\mathrm{L}$ & 50 & 69 & 42 & 28 & 70 & 49.0 & 12.5 & V/r \\
\hline sagittifolium & & W & 50 & 1 & 0 & 1 & 1 & 1.0 & 0.0 & $v r$ \\
\hline & Petiole & $L$ & 50 & 13 & 31 & 32 & 63 & 55.0 & 6.0 & C \\
\hline & & W & 50 & 29 & 0.5 & 1 & 1.5 & 1.0 & 0.0 & 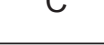 \\
\hline & Root & $\mathrm{L}$ & 50 & 10 & 34 & 32 & 66 & 56.0 & 5.5 & C \\
\hline & & W & 50 & 26 & 1 & 1 & 2 & 1.5 & 0.0 & $c$ \\
\hline & Stem & $\mathrm{L}$ & 50 & 72 & 47 & 25 & 72 & 33.0 & 8.5 & $\mathrm{Br}_{\mathrm{C}}$ \\
\hline & & W & 50 & 65 & 1.5 & 1 & 2.5 & 1.0 & 0.5 & $\mathrm{R}-\mathrm{C}$ \\
\hline Arecaceae: & Fruit & $\mathrm{L}$ & 50 & 37 & 254 & 196 & 450 & 352.0 & 65.0 & $\Delta h$ \\
\hline Caryota mitis & & W & 50 & 41 & 8 & 4.5 & 12.5 & 9.0 & 2.0 & $A b$ \\
\hline & Leaf & $\mathrm{L}$ & 50 & 125 & 99 & 31 & 130 & 69.0 & 23.5 & $A b-$ \\
\hline & & W & 50 & 118 & 3 & 1 & 4 & 2.5 & 1.0 & Vab \\
\hline & Rachis & $\mathrm{L}$ & 4 & 32 & 38 & 72 & 110 & 95.0 & 16.0 & $\mathrm{R}$ \\
\hline & & W & 4 & 12 & 0.5 & 2.5 & 3 & 3.0 & 0.5 & $\mathrm{R}$ \\
\hline & Root & $\mathrm{L}$ & 50 & 295 & 312 & 88 & 400 & 172.5 & 90.0 & $B_{-}-\mathrm{C}$ \\
\hline & & W & 50 & 289 & 9 & 2 & 11 & 4.5 & 2.5 & \\
\hline & Seed & $\mathrm{L}$ & 50 & 62 & 270 & 180 & 450 & 308.0 & 74.0 & $C_{-}-A b$ \\
\hline & & W & 50 & 49 & 7 & 5 & 12 & 8.5 & 2.0 & $C-A D$ \\
\hline & Stem & $\mathrm{L}$ & 50 & 115 & 129 & 41 & 170 & 90.0 & 29.5 & \\
\hline & & W & 50 & 63 & 2.5 & 1 & 3.5 & 2.5 & 0.5 & C-Ab \\
\hline Caryota & Leaf & $\mathrm{L}$ & 50 & 482 & 169 & 24 & 193 & 63.5 & 42.5 & r \\
\hline rumphiana & & W & 50 & 453 & 4 & 1 & 5 & 1.5 & 1.0 & U \\
\hline & Rachis & $\mathrm{L}$ & 50 & 80 & 120 & 42 & 162 & 93.0 & 25.5 & C \\
\hline & & W & 50 & 51 & 2.5 & 1.5 & 4 & 2.5 & 0.5 & c \\
\hline & Stem & $\mathrm{L}$ & 50 & 93 & 104 & 36 & 140 & 95.0 & 28.0 & C \\
\hline & & W & 50 & 80 & 3 & 1 & 4 & 2.5 & 0.5 & C \\
\hline & Wood & $\mathrm{L}$ & 50 & 13 & 25 & 23 & 48 & 39.5 & 4.5 & C \\
\hline & & W & 50 & 50 & 1 & 1 & 2 & 1.0 & 0.0 & C \\
\hline Cocos nucifera & Leaf & $\mathrm{L}$ & 50 & 32 & 32 & 23 & 55 & 37.0 & 6.5 & \\
\hline & & $\mathrm{W}$ & 50 & 26 & 0.5 & 1 & 1.5 & 1.0 & 0.0 & C \\
\hline & Rachis & $\mathrm{L}$ & 50 & 28 & 33 & 30 & 63 & 43.0 & 7.0 & C \\
\hline & & W & 50 & 82 & 1 & 1 & 2 & 1.5 & 0.5 & C \\
\hline & Root & $\mathrm{L}$ & 50 & 31 & 21 & 25 & 46 & 34.0 & 5.5 & 8 \\
\hline & & W & 50 & 23 & 0.5 & 1 & 1.5 & 1.0 & 0.0 & R-C \\
\hline & Wood & $\mathrm{L}$ & 50 & 27 & 30 & 25 & 55 & 38.0 & 6.0 & r \\
\hline & & W & 50 & 78 & 1 & 1 & 2 & 1.0 & 0.5 & C \\
\hline
\end{tabular}




\begin{tabular}{|c|c|c|c|c|c|c|c|c|c|c|}
\hline Family: Species & Organ & $\begin{array}{l}\mathrm{L} / \mathrm{W} \\
(\mu \mathrm{m})\end{array}$ & $n$ & $n_{\text {min }}{ }^{a}$ & Range & $\begin{array}{l}\text { Min } \\
(\mu \mathrm{m})\end{array}$ & $\begin{array}{l}\text { Max } \\
(\mu \mathrm{m})\end{array}$ & $\begin{array}{c}\text { Mean }^{b} \\
(\mu \mathrm{m})\end{array}$ & $\begin{array}{c}\text { St } \\
\text { dev }^{b}\end{array}$ & Freq $^{\mathrm{c}}$ \\
\hline \multirow{10}{*}{$\begin{array}{l}\text { Dioscoreaceae: } \\
\text { Dioscorea } \\
\text { bulbifera }\end{array}$} & \multirow[t]{2}{*}{ Bulbil } & L & 50 & 77 & 68 & 10 & 78 & 52.5 & 14.0 & \multirow{2}{*}{ R-C } \\
\hline & & W & 50 & 79 & 1.5 & 0.5 & 2 & 1.5 & 0.5 & \\
\hline & \multirow[t]{2}{*}{ Leaf } & $L$ & 50 & 22 & 36 & 36 & 72 & 57.0 & 8.0 & \multirow{2}{*}{ C } \\
\hline & & W & 50 & 85 & 1 & 1 & 2 & 1.0 & 0.5 & \\
\hline & \multirow[t]{2}{*}{ Root } & L & 50 & 149 & 120 & 30 & 150 & 66.0 & 24.5 & \multirow{2}{*}{$A b$} \\
\hline & & W & 50 & 129 & 2.5 & 1 & 3.5 & 1.5 & 0.5 & \\
\hline & \multirow[t]{2}{*}{ Stem } & $L$ & 50 & 34 & 38 & 35 & 73 & 49.5 & 9.0 & \multirow{2}{*}{$C-A b$} \\
\hline & & W & 50 & 44 & 1 & 1 & 2 & 1.5 & 0.5 & \\
\hline & \multirow[t]{2}{*}{ Tuber } & $\mathrm{L}$ & 50 & 84 & 91 & 22 & 113 & 73.0 & 20.5 & \multirow{2}{*}{$A b$} \\
\hline & & W & 50 & 81 & 2 & 1 & 3 & 2.0 & 0.5 & \\
\hline \multirow{6}{*}{$\begin{array}{l}\text { Dioscorea } \\
\text { esculenta }\end{array}$} & \multirow[t]{2}{*}{ Leaf } & $\mathrm{L}$ & 50 & 84 & 55 & 30 & 85 & 51.5 & 14.5 & \multirow{2}{*}{ C } \\
\hline & & W & 50 & 88 & 1 & 1 & 2 & 1.0 & 0.5 & \\
\hline & \multirow[t]{2}{*}{ Stem } & $\mathrm{L}$ & 50 & 31 & 39 & 21 & 60 & 45.0 & 7.5 & \multirow{2}{*}{ C } \\
\hline & & W & 50 & 49 & 1 & 0.5 & 1.5 & 1.0 & 0.0 & \\
\hline & \multirow[t]{2}{*}{ Tuber } & $L$ & 50 & 81 & 69 & 25 & 94 & 64.0 & 17.5 & \multirow{2}{*}{$A b$} \\
\hline & & W & 50 & 92 & 1.5 & 1 & 2.5 & 1.5 & 0.5 & \\
\hline Dioscorea hispida & Leaf & L & 50 & 24 & 50 & 40 & 90 & 57.5 & 8.5 & \\
\hline & & $\mathrm{W}$ & 50 & 34 & 1.5 & 1 & 2.5 & 1.5 & 0.5 & $C-A b$ \\
\hline & Petiole & $\mathrm{L}$ & 50 & 23 & 31 & 32 & 63 & 45.5 & 6.5 & $c$ \\
\hline & & W & 50 & 43 & 1 & 1 & 2 & 1.5 & 0.5 & C \\
\hline & Stem & $L$ & 50 & 17 & 32 & 36 & 68 & 50.0 & 6.5 & \\
\hline & & W & 50 & 25 & 1 & 1 & 2 & 1.5 & 0.0 & $A b$ \\
\hline & Tuber & $\mathrm{L}$ & 50 & 21 & 57 & 55 & 112 & 86.5 & 12.0 & \\
\hline & & W & 50 & 21 & 1.5 & 1 & 2.5 & 2.0 & 0.5 & $A b$ \\
\hline Heliconiaceae: & Flower & L & 50 & 48 & 69 & 43 & 112 & 78.0 & 16.5 & C \\
\hline Heliconia indica & & W & 50 & 86 & 1.5 & 0.5 & 2 & 1.0 & 0.5 & C \\
\hline & Fruit & $\mathrm{L}$ & 50 & 112 & 180 & 55 & 235 & 125.0 & 40.0 & \\
\hline & & W & 50 & 50 & 2.5 & 1.5 & 4 & 2.5 & 0.5 & C \\
\hline & Leaf & $\mathrm{L}$ & 50 & 145 & 174 & 10 & 184 & 96.5 & 35.5 & \\
\hline & & W & 50 & 142 & 2.5 & 1 & 3.5 & 1.5 & 0.5 & C \\
\hline & Root & $L$ & 50 & 690 & 175 & 25 & 200 & 43.5 & 35.0 & $\Delta h$ \\
\hline & & W & 50 & 216 & 2.5 & 1 & 3.5 & 1.0 & 0.5 & $A D$ \\
\hline & Tuber & $\mathrm{L}$ & 50 & 108 & 130 & 46 & 176 & 96.0 & 30.5 & $C$ \\
\hline & & W & 50 & 113 & 2.5 & 1 & 3.5 & 2.0 & 0.5 & C \\
\hline Laxmanniaceae: & Leaf & $\mathrm{L}$ & 50 & 27 & 34 & 36 & 70 & 54.0 & 8.5 & \\
\hline Cordyline & & W & 50 & 62 & 1 & 1 & 2 & 1.5 & 0.5 & Vab \\
\hline & Petiole & $\mathrm{L}$ & 50 & 26 & 39 & 41 & 80 & 57.5 & 7.0 & \\
\hline & & W & 50 & 62 & 1 & 1 & 2 & 1.5 & 0.5 & Vab \\
\hline & Root & $\mathrm{L}$ & 50 & 16 & 15 & 25 & 40 & 34.0 & 4.0 & Vab \\
\hline & & $\mathrm{W}$ & 50 & 1 & 0 & 1 & 1 & 1.0 & 0.0 & vap \\
\hline & Stem & $\mathrm{L}$ & 50 & 38 & 63 & 40 & 103 & 68.0 & 12.5 & Vah \\
\hline & & W & 50 & 70 & 2 & 1 & 3 & 1.5 & 0.5 & vap \\
\hline Musaceae: & Bract & $\mathrm{L}$ & 50 & 61 & 98 & 47 & 145 & 89.5 & 21.5 & $C$ \\
\hline Musa acuminata & & W & 50 & 61 & 2 & 1 & 3 & 1.5 & 0.5 & C \\
\hline & Fruit & $L$ & 2 & 66 & 19 & 45 & 64 & 54.5 & 13.5 & $R$ \\
\hline & & $W$ & 2 & 1 & 0 & 1 & 1 & 1.0 & 0.0 & $\mathrm{R}$ \\
\hline & Leaf & $\mathrm{L}$ & 50 & 35 & 60 & 30 & 90 & 57.0 & 10.0 & $R$ \\
\hline & & $W$ & 50 & 6 & 0.5 & 0.5 & 1 & 1.0 & 0.0 & $\mathrm{R}$ \\
\hline & Petiole & $\mathrm{L}$ & 50 & 263 & 177 & 29 & 206 & 110.5 & 54.5 & $\mathrm{R}$ \\
\hline & & W & 50 & 284 & 3 & 1 & 4 & 2.0 & 1.0 & $\mathrm{R}$ \\
\hline
\end{tabular}




\begin{tabular}{|c|c|c|c|c|c|c|c|c|c|c|}
\hline Family: Species & Organ & $\begin{array}{l}\mathrm{L} / \mathrm{W} \\
(\mu \mathrm{m})\end{array}$ & $n$ & $n_{\min }{ }^{a}$ & Range & $\begin{array}{l}\text { Min } \\
(\mu \mathrm{m})\end{array}$ & $\begin{array}{l}\text { Max } \\
(\mu \mathrm{m})\end{array}$ & $\begin{array}{c}\text { Mean }^{b} \\
(\mu \mathrm{m})\end{array}$ & $\begin{array}{c}\text { St } \\
\operatorname{dev}^{b}\end{array}$ & Freq $^{\circ}$ \\
\hline \multirow[t]{8}{*}{ Musa ingens } & \multirow[t]{2}{*}{ Bract } & $\mathrm{L}$ & 50 & 27 & 43 & 25 & 68 & 46.5 & 7.5 & \multirow{2}{*}{ Vab } \\
\hline & & W & 50 & 81 & 1 & 1 & 2 & 1.5 & 0.5 & \\
\hline & Leaf & - & 0 & - & - & - & - & - & - & A \\
\hline & \multirow{2}{*}{ Flower } & $\mathrm{L}$ & 50 & 48 & 39 & 31 & 70 & 43.5 & 9.0 & \multirow{2}{*}{ Vab } \\
\hline & & W & 50 & 84 & 1 & 1 & 2 & 1.5 & 0.5 & \\
\hline & Petiole & - & 0 & - & - & - & - & - & - & $A$ \\
\hline & \multirow{2}{*}{$\begin{array}{l}\text { Pseudo- } \\
\text { stem }\end{array}$} & $\mathrm{L}$ & 50 & 84 & 72 & 33 & 105 & 62.5 & 17.5 & \multirow{2}{*}{$\mathrm{R}$} \\
\hline & & W & 50 & 109 & 2 & 1 & 3 & 1.5 & 0.5 & \\
\hline \multirow[t]{8}{*}{ Musa maclayi } & \multirow[t]{2}{*}{ Bract } & $\mathrm{L}$ & 50 & 38 & 53 & 40 & 93 & 58.0 & 11.0 & \multirow{2}{*}{$C-A b$} \\
\hline & & W & 50 & 23 & 0.5 & 1 & 1.5 & 1.0 & 0.0 & \\
\hline & Flower & - & 0 & - & - & - & - & - & - & $A$ \\
\hline & \multirow[t]{2}{*}{ Leaf } & $\mathrm{L}$ & 50 & 36 & 57 & 25 & 82 & 62.5 & 11.5 & \multirow{2}{*}{ C } \\
\hline & & W & 50 & 34 & 0.5 & 1 & 1.5 & 1.0 & 0.0 & \\
\hline & Fruit & - & 0 & - & - & - & - & - & - & $A$ \\
\hline & \multirow[t]{2}{*}{ Petiole } & $\mathrm{L}$ & 50 & 23 & 49 & 75 & 124 & 97.0 & 14.0 & \multirow{2}{*}{ Vab } \\
\hline & & W & 50 & 121 & 2 & 1 & 3 & 2.0 & 0.5 & \\
\hline \multirow{6}{*}{$\begin{array}{l}\text { Pandanaceae: } \\
\text { Pandanus dubius }\end{array}$} & \multirow[t]{2}{*}{ Leaf } & $\mathrm{L}$ & 50 & 259 & 74 & 10 & 84 & 40.5 & 19.5 & \multirow{2}{*}{$\mathrm{C}$} \\
\hline & & W & 50 & 60 & 1 & 1 & 2 & 1.0 & 0.5 & \\
\hline & \multirow[t]{2}{*}{ Root } & $\mathrm{L}$ & 50 & 85 & 59 & 21 & 80 & 47.0 & $13.0^{4}$ & \multirow{2}{*}{$A b$} \\
\hline & & W & 50 & 95 & 1.5 & 1 & 2.5 & 1.0 & 0.5 & \\
\hline & \multirow[t]{2}{*}{ Wood } & $\mathrm{L}$ & 50 & 145 & 60 & 20 & 80 & 41.5 & 15.0 & \multirow{2}{*}{ Vab } \\
\hline & & W & 50 & 86 & 1 & 1 & 2 & 1.0 & 0.5 & \\
\hline \multirow{6}{*}{$\begin{array}{l}\text { Pandanus } \\
\text { tectorius }\end{array}$} & \multirow[t]{2}{*}{ Leaf } & $\mathrm{L}$ & 50 & 571 & 105 & 15 & 120 & 43.5 & 31.5 & \multirow{2}{*}{ C } \\
\hline & & W & 50 & 86 & 1 & 1 & 2 & 1.0 & 0.5 & \\
\hline & \multirow[t]{2}{*}{ Root } & $\mathrm{L}$ & 50 & 77 & 60 & 25 & 85 & 5.0 & 14.0 & \multirow{2}{*}{$A b$} \\
\hline & & W & 50 & 58 & 1 & 0.5 & 1.5 & 1.0 & 0.5 & \\
\hline & \multirow[t]{2}{*}{ Wood } & $\mathrm{L}$ & 50 & 274 & 90 & 22 & 112 & 58.5 & 29.5 & \multirow{2}{*}{ C-Ab } \\
\hline & & W & 50 & 98 & 1.5 & 1 & 2.5 & 1.0 & 0.5 & \\
\hline \multicolumn{11}{|c|}{$\begin{array}{l}{ }^{a} \text { Average } n_{\min }=96 . \\
\text { b Rounded to the nearest } 0.5 \mu \mathrm{m} \text {. } \\
{ }^{\mathrm{c}} \text { Frequency (Freq) key: } \mathrm{A}-\text { absent, } \mathrm{Vr} \text { - very rare, } \mathrm{R}-\text { rare, } \mathrm{C}-\text { common, Ab - abundant, Vab - very } \\
\text { abundant. }\end{array}$} \\
\hline
\end{tabular}
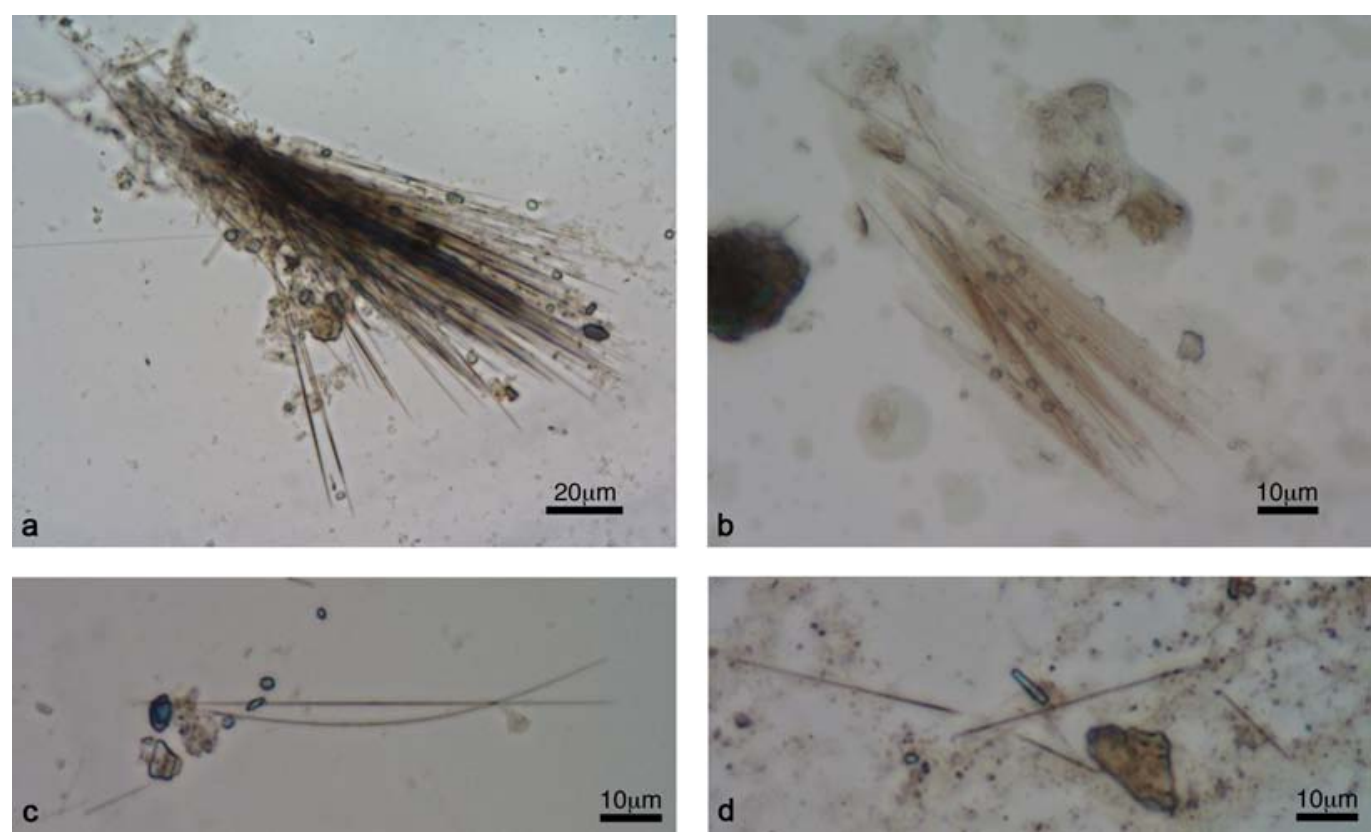

Figure 11. Examples of whisker raphides: (a) Colocasia esculenta (leaf); (b) Musa maclayi (fruit); (c) curved aroid whiskers (Alocasia macrorrhiza, stem); and (d) Pandanus dubius (root) [all images transmitted light]. 


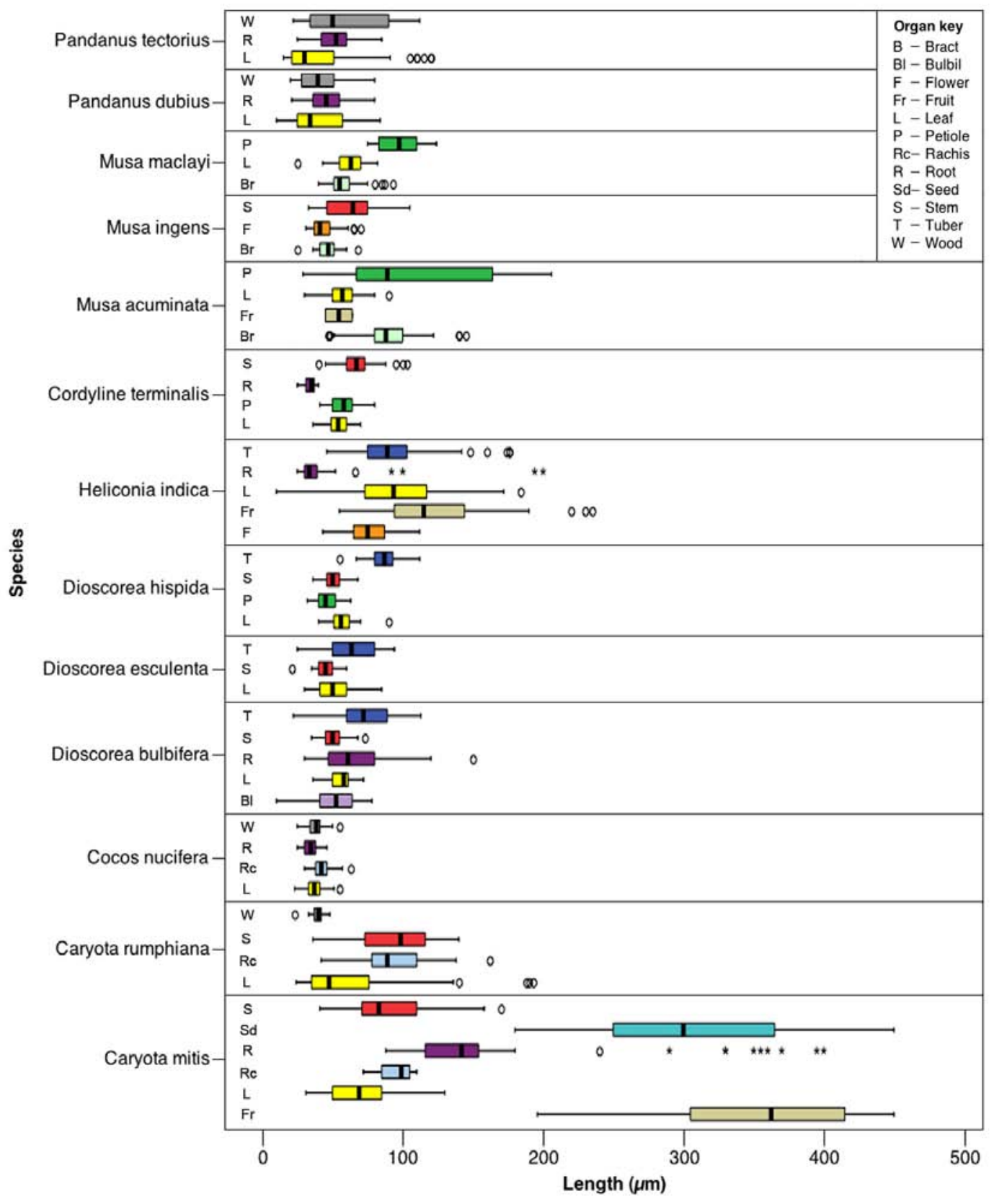

Figure 12. Box-and-whisker plot showing the spread of raphide lengths about the mean for species classified in the Type I/III morphological group.

All remaining taxa produce either Type I or Type III morphologies, which overlap depending on crystal maturity. The most diagnostic attribute of aroid raphides is the $\mathrm{H}$-shaped cross-section or, as seen in plane view, the presence of longitudinal grooves on opposing faces of the crystal. These features are sometimes visible by light microscopy depending largely on raphide size, but can generally be seen on all aroid raphides, regardless of overall size or degree of fragmentation, using SEM. Although asymmetrical terminations are also unique to Araceae raphides, this feature is not common to all species (e.g. Cyrtosperma spp. have symmetrical tapered ends). Terminations may also be missing from fragmented archaeological crystals owing to their fragility, although the short wedge-shaped end, if present, may further support the identification of aroid raphides. Based on these observations, this study has demonstrated that it is possible to at least differentiate aroid from non-aroid taxa based on raphide morphology alone. Despite its broadness, this level of classification is significant given the importance of the edible aroids to past and present subsistence regimes in the Pacific Islands. 
Table 7. Results of the intra-species MANOVA (Pillai's Trace) and ANOVA tests. Nonsignificant results are shown in bold

\begin{tabular}{|c|c|c|c|c|c|c|c|c|c|c|c|c|}
\hline \multirow{3}{*}{$\begin{array}{l}\text { Species } \\
\text { Alocasia macrorrhiza }\end{array}$} & \multicolumn{4}{|c|}{ MANOVA } & \multicolumn{4}{|c|}{ ANOVA (length) } & \multicolumn{4}{|c|}{ ANOVA (width) } \\
\hline & \multicolumn{2}{|r|}{$d f$} & \multirow{2}{*}{$\begin{array}{c}\boldsymbol{F} \\
66.29 \\
\end{array}$} & \multirow{2}{*}{$\begin{array}{c}\boldsymbol{p}^{\mathbf{a}} \\
<0.001\end{array}$} & \multicolumn{2}{|c|}{$d f$} & \multirow{2}{*}{$\begin{array}{c}\boldsymbol{F} \\
529.16\end{array}$} & \multirow{2}{*}{$\begin{array}{c}\boldsymbol{p}^{b} \\
<0.001\end{array}$} & \multicolumn{2}{|c|}{$d f$} & \multirow{2}{*}{$\begin{array}{c}\boldsymbol{F} \\
529.64\end{array}$} & \multirow{2}{*}{$\begin{array}{c}p^{b} \\
<0.00\end{array}$} \\
\hline & 4 & 292 & & & 2 & 146 & & & 2 & 145 & & \\
\hline Amorphophallus blumei & 6 & 390 & 12.11 & $<0.001$ & 3 & 196 & 25.27 & $<0.001$ & 3 & 196 & 29.05 & $<0.001$ \\
\hline Colocasia esculenta & 6 & 386 & 41.78 & $<0.001$ & 3 & 193 & 118.85 & $<0.001$ & 3 & 194 & 18.59 & $<0.001$ \\
\hline Cyrtosperma johnstonii & 8 & 480 & 28.25 & $<0.001$ & 4 & 242 & 89.44 & $<0.001$ & 4 & 241 & 7.27 & $<0.001$ \\
\hline Xanthosoma sagittifolium & 6 & 384 & 111.20 & $<0.001$ & 3 & 190 & 131.84 & $<0.001$ & 3 & 194 & 139.31 & $<0.001$ \\
\hline Caryota rumphiana & 6 & 388 & 19.42 & $<0.001$ & 4 & 245 & 210.46 & $<0.001$ & 4 & 245 & 203.40 & $<0.001$ \\
\hline Cocos nucifera & 6 & 392 & 10.35 & $<0.001$ & 3 & 194 & 48.18 & $<0.001$ & 3 & 194 & 39.66 & $<0.001$ \\
\hline Caryota mitis & 8 & 488 & 43.32 & $<0.001$ & 3 & 196 & 16.58 & $<0.001$ & 3 & 196 & 16.99 & $<0.001$ \\
\hline Dioscorea bulbifera & 8 & 490 & 22.99 & $<0.001$ & 4 & 243 & 18.54 & $<0.001$ & 4 & 244 & 23.00 & $<0.001$ \\
\hline Dioscorea esculenta & 4 & 294 & 11.01 & $<0.001$ & 2 & 146 & 24.07 & $<0.001$ & 2 & 147 & 18.28 & $<0.001$ \\
\hline Dioscorea hispida & 6 & 390 & 55.86 & $<0.001$ & 3 & 195 & 244.68 & $<0.001$ & 3 & 195 & 47.57 & $<0.001$ \\
\hline Heliconia indica & 8 & 484 & 49.05 & $<0.001$ & 4 & 243 & 59.47 & $<0.001$ & 4 & 242 & 86.49 & $<0.001$ \\
\hline Cordyline terminalis & 6 & 392 & 32.29 & $<0.001$ & 3 & 196 & 122.77 & $<0.001$ & 3 & 195 & 39.68 & $<0.001$ \\
\hline Musa acuminata & 4 & 292 & 14.16 & $<0.001$ & 2 & 146 & 31.14 & $<0.001$ & 2 & 145 & 34.41 & $<0.001$ \\
\hline Musa ingens & 4 & 292 & 23.51 & $<0.001$ & 2 & 147 & 35.25 & $<0.001$ & 2 & 146 & 2.463 & 0.089 \\
\hline Musa maclayi & 4 & 294 & 38.31 & $<0.001$ & 2 & 145 & 176.50 & $<0.001$ & 2 & 143 & 58.91 & $<0.001$ \\
\hline Pandanus dubius & 4 & 294 & 1.20 & 0.312 & 2 & 147 & 2.43 & 0.091 & 2 & 144 & 1.735 & 0.180 \\
\hline Pandanus tectorius & 4 & 290 & 6.91 & $<0.001$ & 2 & 147 & 4.34 & 0.015 & 2 & 146 & 1.807 & 0.168 \\
\hline
\end{tabular}

Table 8. Results of the inter-species MANOVA (Pillai's Trace) and ANOVA tests within the Type I/III and Type IV (Araceae) morphological group. Non-significant differences are shown in bold

\begin{tabular}{|c|c|c|c|c|c|c|c|c|c|c|c|c|c|}
\hline \multirow{2}{*}{ Group } & \multirow{2}{*}{ Organ } & \multicolumn{4}{|c|}{ MANOVA } & \multicolumn{4}{|c|}{ ANOVA (length) } & \multicolumn{4}{|c|}{ ANOVA (width) } \\
\hline & & \multicolumn{2}{|c|}{$d f$} & \multirow{2}{*}{$\frac{\boldsymbol{F}}{76.03}$} & \multirow{2}{*}{$\begin{array}{c}\boldsymbol{p}^{\mathbf{a}} \\
<0.001\end{array}$} & \multicolumn{2}{|c|}{$d f$} & \multirow{2}{*}{$\begin{array}{c}\boldsymbol{F} \\
124.73\end{array}$} & \multirow{2}{*}{$\begin{array}{c}\boldsymbol{p}^{b} \\
<0.001\end{array}$} & \multicolumn{2}{|c|}{$d f$} & \multirow{2}{*}{$\begin{array}{c}\boldsymbol{F} \\
48.20\end{array}$} & \multirow{2}{*}{$\begin{array}{c}p^{b} \\
<0.001\end{array}$} \\
\hline \multirow{10}{*}{$\begin{array}{l}\text { Type I/ } \\
\text { III }\end{array}$} & Bract & 4 & 294 & & & 2 & 146 & & & 2 & 146 & & \\
\hline & Flower & 2 & 96 & 180.48 & $<0.001$ & 1 & 98 & 166.38 & $<0.001$ & 1 & 98 & 8.90 & 0.004 \\
\hline & Fruit & 2 & 97 & 312.34 & $<0.001$ & 1 & 98 & 441.01 & $<0.001$ & 1 & 98 & 630.82 & $<0.001$ \\
\hline & Leaf & 22 & 1170 & 38.75 & $<0.001$ & 11 & 584 & 27.364 & $<0.001$ & 11 & 584 & 32.47 & $<0.001$ \\
\hline & Petiole & 6 & 392 & 28.27 & $<0.001$ & 3 & 196 & 58.46 & $<0.001$ & 3 & 196 & 12.77 & $<0.001$ \\
\hline & Rachis & 2 & 97 & 91.41 & $<0.001$ & 1 & 98 & 182.05 & $<0.001$ & 1 & 97 & 110.86 & $<0.001$ \\
\hline & Root & 12 & 678 & 37.13 & $<0.001$ & 6 & 340 & 92.52 & $<0.001$ & 6 & 339 & 97.48 & $<0.001$ \\
\hline & Stem & 12 & 686 & 33.99 & $<0.001$ & 6 & 342 & 61.67 & $<0.001$ & 6 & 341 & 77.04 & $<0.001$ \\
\hline & Tuber & 6 & 390 & 25.18 & $<0.001$ & 3 & 196 & 22.65 & $<0.001$ & 3 & 195 & 7.31 & $<0.001$ \\
\hline & Wood & 6 & 388 & 9.16 & $<0.001$ & 3 & 195 & 15.75 & $<0.001$ & 3 & 194 & 0.66 & 0.581 \\
\hline \multirow{5}{*}{$\begin{array}{l}\text { Ty p e } \\
\text { IV }\end{array}$} & Flower & 2 & 96 & 24.37 & $<0.001$ & 1 & 96 & 38.36 & $<0.001$ & 1 & 96 & 1.140 & 0.288 \\
\hline & Leaf & 8 & 484 & 19.60 & $<0.001$ & 4 & 244 & 41.40 & $<0.001$ & 4 & 242 & 42.30 & $<0.001$ \\
\hline & Petiole & 6 & 390 & 17.16 & $<0.001$ & 3 & 193 & 11.54 & $<0.001$ & 3 & 196 & 18.18 & $<0.001$ \\
\hline & Root & 6 & 388 & 68.14 & $<0.001$ & 3 & 193 & 2128.40 & $<0.001$ & 3 & 195 & 1080.84 & $<0.001$ \\
\hline & Tuber & 8 & 480 & 78.34 & $<0.001$ & 4 & 241 & 1036.50 & $<0.001$ & 4 & 243 & 390.02 & $<0.001$ \\
\hline
\end{tabular}

In addition to being distinct from all other analysed taxa, aroid raphides were found to differ significantly from one another in terms of the size and location of the central bridge, visibility of grooves by light microscopy and termination shape (see the taxonomic key presented in Table 3 above). The configuration of these features was reasonably consistent within a single species, which is important for taxonomic purposes, and appears to differ between taxa at the genus rather than species level. Although species identifications are highly desirable for residue and microfossil studies, genus-level identifications of aroid raphides are still very useful in the Pacific context. Once again, the main limitation for taxonomic identification is that the presence and configuration of these features can only be observed on whole crystals, which are rarely found in archaeological contexts owing to their fragility. 


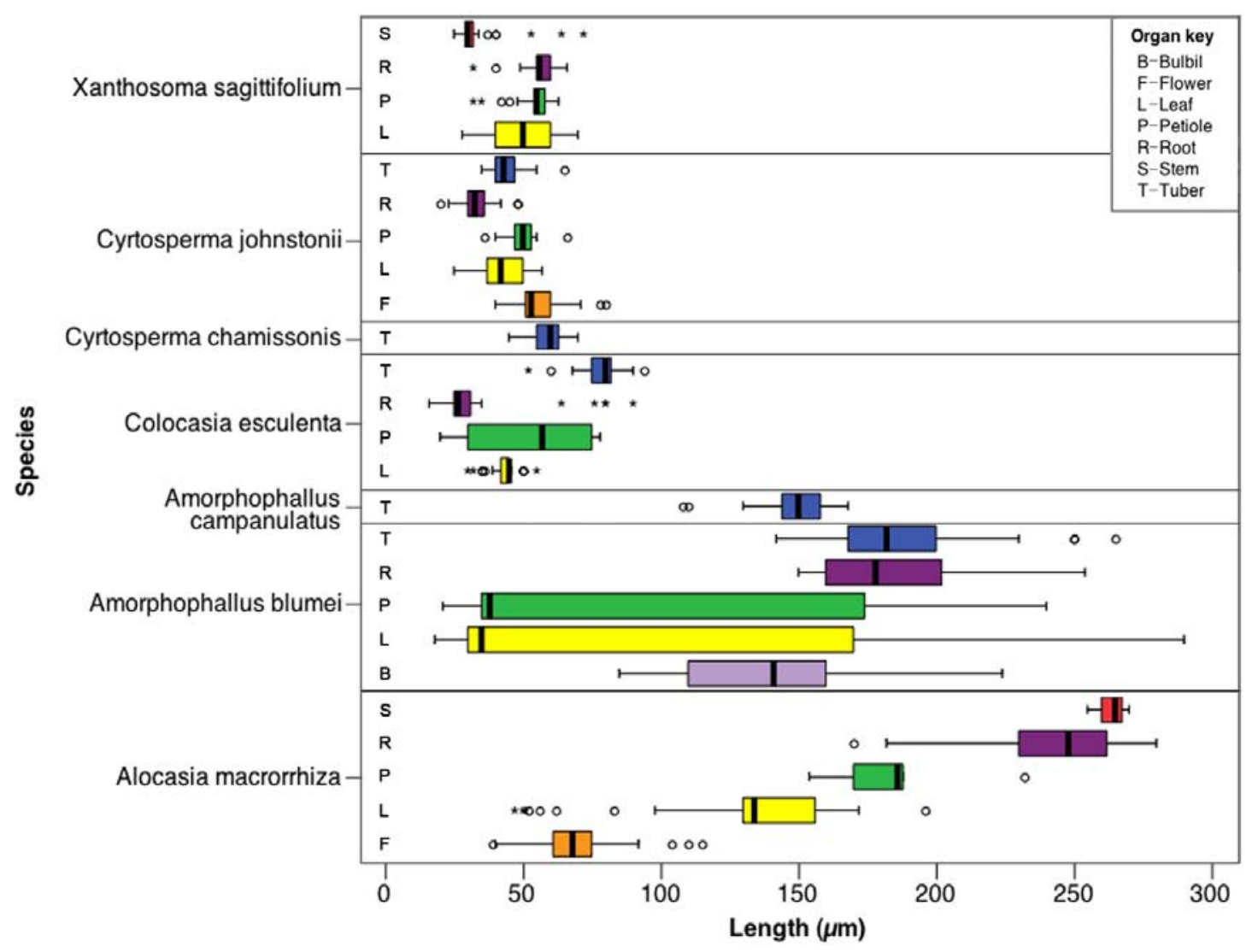

Figure 13. Box-and-whisker plot showing the spread of raphide lengths about the mean for species classified in the Type IV morphological group.

Even though similar raphide forms were generally observed within each species regardless of the plant part studied, minor exceptions did occur that warrant further discussion. For one, the short central bridge typical of Alocasia macrorrhiza raphides was not visible by light microscopy on crystals from the flower, possibly owing to their relative thinness. Because the flower of this species is not likely to contribute significant quantities of raphides to the archaeological record, however, this deviation is not considered problematic for taxonomic determinations. Amorphophallus blumei was the only other species within which significantly different raphide forms were observed. Its typical form has a long bridge that is offset to one end, but the leaf and petiole also produce a shorter, thinner raphide type with a short, central bridge, similar to that of Alocasia macrorrhiza. In cases where large enough raphide assemblages are recovered from archaeological contexts, it may be possible to differentiate these taxa based on the presence of the larger, more diagnostic types, but where only the thin type is found, taxonomic differentiation may be more difficult. Further SEM studies to determine if the smaller A. blumei raphides have the same distinctive protruding termination (SWP) observed on the larger crystals may also prove useful. A consideration in this instance is that Amorphophallus blumei is not presently an economically important species in the Pacific and is less likely to occur in archaeological assemblages from this region if current use reflects past exploitation. The closely related species A. campanulatus is on the other hand both widespread and of minor importance as a food source, and must therefore be investigated more thoroughly to establish if it also produces these different raphide forms.

Additional research is also required to test the hypothesis that aroid raphide morphology is determined at the genus rather than species level as only a limited number of intra-genus comparisons were made in this study. For example, although similar forms were observed within Amorphophallus blumei and A. campanulatus, as well as within Cyrtosperma chamissionis and C. johnstonii, only a single comparative sample within these genera was analysed. Interestingly, the 
distinctive protruding terminations observed on both Amorphophallus species were also reported on raphides from Amorphophallus rivieri by Sakai et al. (1984) and in several Amorphophallus species by Prychid et al. (in press), lending support to the notion that raphide morphology is genera-specific. It may be that calcium oxalate crystal morphology in general is determined at the genus level, considering the similar observation by Jones and Bryant (1992) that druse forms produced by cacti are shared at this level.

The final factor to consider with regard to morphological variation is the possible influence of environmental factors on form. Although this issue was not investigated directly by this study, the observed features of aroid raphides are generally consistent with other published accounts. For example, Bradbury and Nixon (1998) also described the short bridge of Alocasia macrorrhiza raphides, the symmetry and comparatively long bridge of Cyrtosperma chamissonis raphides, as well as the absence of 'thin' (whisker) types from this species. Likewise, Sakai and Hanson (1974:742) noted that while the bridge of Alocasia macrorrhiza raphides is visible by light microscopy, it is not visible on either Colocasia esculenta or Xanthosoma sagittifolium raphides. Even though the bridge was observed on both root and stem raphides from $X$. sagittifolium in this study (see Table 4), Sakai and Hanson did not examine root samples (only corm, stem, petiole and leaf), and raphides with visible bridges were only rarely present in the stem (Table 4). In addition to indicating that morphology is more genetically than environmentally determined, these published observations further validate the applicability of the taxonomic key developed in this study.

By comparison, no potentially diagnostic traits were observed on any Type I and III raphides that could further differentiate taxa from these groups. Although only the Pandanaceae produced exclusively Type I crystals, this form overlaps with immature Type III crystals produced by other non-Pandanaceae taxa. In cases where more mature Type III crystals are present in archaeological assemblages, Pandanus spp. may therefore be discounted as possible taxa of origin, but where only Type I crystals are present (particularly in small assemblages), it will be more difficult to rule out the possibility that they are derived from plants with Type III. Further research is required to determine whether any significant differences in size or shape occur between mature Type I and immature Type III raphides, which might enable confident separation of these groups.

\section{Size variation}

The results of the multivariate tests indicate that raphide size is significantly affected by the organ in which it is produced, which is highly problematic for taxonomic purposes. Not only were there significant differences in the mean sizes of raphides within each species, but size ranges were often highly variable at the species level and also overlapped considerably between species. It is therefore very difficult to demonstrate any meaningful relationship between raphide size and taxa of origin. Owing to the large degree of intra-species size variation, the significant differences detected between species (when like organs were compared) have little taxonomic value except in situations where raphides are derived from a single known organ. This is rarely the case for microfossils extracted from bulk sediment samples, which by-and-large represent whole-plant assemblages, but is feasible in contexts where raphides are directly associated with storage starch granules, such as in use-residues on artefacts. In these cases it may be possible to discriminate plant taxa more effectively if measures of raphide size (and shape) are included in the starch taxonomic key, rather than mere presence/absence measures as used in previous studies (e.g. Loy et al. 1992; Torrence et al. 2004). This could be further tested through discriminant function analysis of combined starch and raphide data for reference materials.

Clearly apparent from the size data is the fact that large raphides (i.e. longer than $\sim 250 \mu \mathrm{m}$ ) are altogether very rare, while raphides longer than $150-200 \mu \mathrm{m}$ are less common among the Araceae (these were only observed in Alocasia macrorrhiza and Amorphophallus spp.). Threshold values may be useful for identifying key taxa if they are found to produce raphides in exceptionally large size ranges. Larger and more comprehensive reference collections must be analysed if such identifications are to be supported. 


\section{Implications for previous archaeological raphide analyses}

Many of the criteria used previously to identify raphides from Colocasia esculenta and other Pacific aroids in microfossil assemblages, including abundance and the presence of the thin, whiskertype have been shown here to be unreliable. Rather, it has been demonstrated that even though raphides are often very abundant in the aroids, they also occur in comparably high frequencies in other taxa. In fact, the highest density across all samples was observed in the wood of Pandanus dubius rather than in the Araceae, although inconsistent sample sizes may have biased this finding. Additionally, no appreciable trend was detected between raphide frequency and either organ or species of origin, suggesting that raphide abundance is not strictly taxonomically or biologically related. It was also found that whisker raphides occur in a number of non-aroid taxa, including Dioscorea hispida, Heliconia indica, Musa maclayi, Pandanus dubius and P. tectorius, indicating that this type is not specific to the Araceae. Analysis of a wider range of reference materials may expand this list further. Curved whisker raphides, on the other hand, have only been observed in the Araceae thus far and may have some diagnostic value.

The results of archaeological analyses that have relied on criteria of raphide abundance and whisker raphide presence (e.g. Crowther 2005; Horrocks and Barber 2005; Horrocks and Bedford 2005; Horrocks and Nunn 2007; Horrocks and Weisler 2006; Horrocks et al. 2007; Loy et al. 1992) should be treated with caution until more detailed morphological analyses using SEM have been made. This is an important issue, as many of these studies have contributed critical evidence for the use and spread of Colocasia esculenta and other aroid genera as well as associated horticultural practices across the Pacific region during prehistory. While most of these reports have used the co-presence of other diagnostic microfossil types such as starch granules to identify these plants archaeologically, raphides have still been drawn on as key corroborating evidence to support these identifications. It is critical, therefore, that the identification of raphides in these studies be as independently secure as possible, for which reference to explicit morphometric criteria such as the presence or absence of a longitudinal groove (to differentiate aroid from non-aroid taxa) must be presented. This is particularly important in cases where an indirect relationship between the raphides and other microfossil types must otherwise be assumed (such as in bulk sediment samples that are likely to contain microfossils from a wide range of taxa), or where plant genus or species have been identified based on the presence of raphides alone. For example, the species identification of $C$. esculenta raphides in the absence of other diagnostic taro-type microfossils at an early wetland ditch in Motutangi, New Zealand (Horrocks and Barber 2005:Figure 6, 110) requires at least some discussion of morphometric attributes in order to be upheld.

\section{CONCLUSION}

This study has demonstrated that there is only limited potential for raphides from different economically-important Pacific plant taxa to be differentiated based on morphometric variables. Specifically, it was found that raphide size varies considerably within species, while similar shapes are shared among a number of taxa, leaving little scope for taxonomic differentiation. The key exceptions were members of the Araceae, which produce raphides that can be separated from all other taxa by the presence of a longitudinal groove, and from each other by the configuration and visibility of morphological features such as terminations and the central bridge. This study has firmly established that routine identifications of aroid raphides from Pacific samples are possible based on the presence of these features alone. Furthermore, in cases where crystals are fragmented or too small to resolve morphological features with light microscopy, it has been shown that such identifications can still be made using SEM. This is a very significant outcome for residue and microfossil studies, considering that aroids are traditionally a major staple in many Pacific Islands societies and that these plants are therefore likely to be represented in archaeological residue assemblages from the region. Previous identifications of aroid raphides from archaeological contexts may also be strengthened if reviewed in light of these criteria, until which time they should be regarded as tentative. 
Although the scope for discriminating between non-aroid taxa based on morphometric variables appears limited at this stage, this potential may increase in contexts where only a restricted range of taxa are likely to be present. In these cases, size may have greater significance, particularly if larger and much rarer types are present. Stronger identifications may also be achieved in cases where raphides co-occur in direct association with other distinctive microfossils, such as starch granules or phytoliths, as a much wider range of attributes can then be used to differentiate taxa. This possibility could be further tested by incorporating the data from this study into multivariate statistical models developed for the taxonomic analysis of starch granules (e.g. Loy et al. 1992; Torrence et al. 2004).

\section{ACKNOWLEDGEMENTS}

I thank Carol Lentfer for generously providing plant reference materials, Kim Sewell and other staff at The University of Queensland's Centre for Microscopy and Microanalysis for assistance during SEM, and Michael Haslam and an anonymous reviewer for their helpful comments on an earlier draft of this paper. Funding for this study was provided by the School of Social Science, The University of Queensland.

\section{REFERENCES}

Arnott, H.J. 1981 An SEM study of twinning in calcium oxalate crystals of plants. Scanning Electron Microscopy 1981(III):225-234.

Arnott, H.J. and F.G.E. Pautard 1970 Calcification in plants. In H. Schraer (ed.) Biological Calcification: Cellular and molecular aspects, pp. 375-446. New York: Appleton-CenturyCrofts.

Arnott, H.J. and M.A. Webb 2000 Twinned raphides of calcium oxalate in grape (vitis): implications for crystal stability and function. International Journal of Plant Science 161(1):133-142.

Ayensu, E.S. 1972 Anatomy of the Monocotyledons VI: Dioscoreales. Oxford: Clarendon Press.

Barrau, J. 1958 Subsistence Agriculture in Melanesia. Bernice P. Bishop Museum Bulletin 219. Honolulu: Bernice P. Bishop Museum.

Bouropoulos, N., S. Weiner and L. Addadi 2001 Calcium oxalate crystals in tomato and tobacco plants: morphology and in vitro interactions of crystal-associated macromolecules. Chemistry - A European Journal 7(9):1881-1888.

Bradbury, J.H. and R.W. Nixon 1998 The acridity of raphides from the edible aroids. Journal of the Science of Food and Agriculture 76:608-616.

Cervantes-Martinez, T., H.T. Horner, Jr, R.G. Palmer, T. Hymowitz and A.H.D. Brown 2005 Calcium oxalate crystal macropatterns in leaves of species from groups Glycine and Shuteria (Glycininae; Phaseoleae; Papilionoideae; Fabaceae). Canadian Journal of Botany 83(11):1410-1421.

Cody, A.M. and H.T. Horner 1983 Twin raphides in the Vitaceae and Araceae and a model for their growth. Botanical Gazette 144(3):318-330.

Crowther, A. 2005 Starch residues on undecorated Lapita pottery from Anir, New Ireland. Archaeology in Oceania 40:62-66.

Crowther, A. In Press Reviewing raphides: issues with the identification and interpretation of calcium oxalate crystals in microfossil assemblages. In A. Fairbairn and S. O'Connor (eds) Proceedings of the 2005 Australasian Archaeometry Conference. Canberra: ANU E Press. 
Drennan, R.D. 1996 Statistics for Archaeologists: A commonsense approach. New York: Plenum.

Field, A. 2005 Discovering Statistics Using SPSS. 2nd edn. London: Sage Publications.

Fullagar, R.L.K., J. Field, T.P. Denham and C.J. Lentfer 2006 Early and mid Holocene tool-use and processing of taro (Colocasia esculenta), yam (Dioscorea sp.) and other plants at Kuk Swamp in the highlands of Papua New Guinea. Journal of Archaeological Science 33:595614.

Franceschi, V.R. and H.T. Horner, Jr 1980 Calcium oxalate crystals in plants. The Botanical Review 46(4):361-427.

Franceschi, V.R. and P.A. Nakata 2005 Calcium oxalate in plants: formation and function. Annual Review of Plant Biology 56:41-71.

Hartl, W.P., H. Klapper, B. Barbier, H.J. Ensikat, R. Dronskowski, P. Müller, G. Ostendorp, A. Tye, R. Bauer and W. Barthlott 2007 Diversity of calcium oxalate crystals in Cactaceae. Canadian Journal of Botany 85(5):501-517.

Hather, J.G. 1992 The archaeobotany of subsistence in the Pacific world. Archaeology in Oceania 24(1):70-81.

Horner, H.T., A.P. Kausch and B.L. Wagner 1981 Growth and change in shape of raphide and druse calcium oxalate crystals as a function of intracellular development in Typha angustifolia L. (Typhaceae) and Capsicum annuum L. (Solanaceae). Scanning Electron Microscopy 1981(III):251-262.

Horner, H.T., and B.L. Wagner 1995 Calcium oxalate formation in higher plants. In S.R. Khan (ed.) Calcium Oxalate in Biological Systems, pp. 53-72. Boca Raton, Florida: CRC Press.

Horrocks, M. and I. Barber 2005 Microfossils of introduced starch cultigens from an early wetland ditch in New Zealand. Archaeology in Oceania 40:106-114.

Horrocks, M. and S. Bedford 2005 Microfossil analysis of Lapita deposits in Vanuatu reveal introduced Araceae. Archaeology in Oceania 40:67-74.

Horrocks, M., S. Bulmer and R.O. Gardner 2008a Plant microfossils in prehistoric archaeological deposits from Yuku rock shelter, Western Highlands, Papua New Guinea. Journal of Archaeological Science 35:290-301.

Horrocks, M., J.A. Grant-Mackie and E.A. Matisoo-Smith 2008b Introduced taro (Colocasia esculenta) and yams (Dioscorea spp.) in Podtanean (2700-1800 years BP) deposits from Mé Auré Cave (WMD007), Moindou, New Caledonia. Journal of Archaeological Science 35(1):169-180.

Horrocks, M., S.I. Nichol, P.C. Augustinus and I.G. Barber 2007 Late Quaternary environments, vegetation and agriculture in northern New Zealand. Journal of Quaternary Science 22(3):267-279.

Horrocks, M. and P.D. Nunn 2007 Evidence for introduced taro (Colocasia esculenta) and lesser yam (Dioscorea esculenta) in Lapita-era (c. 3050-2500 cal. yr BP) deposits from Bourewa, southwest Viti Levu Island, Fiji. Journal of Archaeological Science 34:739-748.

Horrocks, M. and M.I. Weisler 2006 Analysis of plant microfossils in archaeological deposits from two remote archipelagos: the Marshall Islands, eastern Micronesia, and the Pitcairn Group, southeast Polynesia. Pacific Science 60(2):261-280. 
Jones, J.G. and V.M. Bryant 1992 Phytolith taxonomy in selected species of Texas cacti. In G. Rapp, Jr. and S.C. Mulholland (eds) Phytolith Systematics: Emerging issues, pp. 215-238. New York: Plenum Press.

Kausch, A.P. and H.T. Horner 1982 A comparison of calcium oxalate crystals isolated from callus cultures and their explant sources. Scanning Electron Microscopy 1982(I):199-211.

Kostman, T.A. and V.R. Franceschi 2000 Cell and calcium oxalate crystal growth is coordinated to achieve high-capacity calcium regulation in plants. Protoplasma 214:166-179.

Lentfer, C.J. and R.C. Green 2004 Phytoliths and the evidence for banana cultivation at the Lapita Reber-Rakival Site on Watom Island, Papua New Guinea. In V. Attenbrow and R.L.K. Fullagar (eds) A Pacific Odyssey: Archaeology and anthropology in the western Pacific. Papers in honour of Jim Specht, pp. 75-88. Records of the Australian Museum, Supplement 29. Sydney: Australian Museum.

Lersten, N.R. and H.T. Horner, Jr 2000 Calcium oxalate crystal types and trends in their distribution pattern in leaves of Prunus (Rosaceae: Prunoideae). Plant Systematics and Evolution 224:83-96.

Lersten, N.R. and H.T. Horner, Jr 2008 Crystal macropatterns in leaves of Fagaceae and Nothofagaceae: a comparative study. Plant Systematics and Evolution 271:239-253.

Loy, T.H. 1994 Methods in the analysis of starch residues on prehistoric stone tools. In J.G. Hather (ed.) Tropical Archaeobotany: Applications and new developments, pp. 86-114. London: Routledge.

Loy, T.H., M. Spriggs and S. Wickler 1992 Direct evidence for human use of plants 28,000 years ago: starch residues on stone artefacts from the northern Solomon Islands. Antiquity 66(253):898-912.

Madella, M., A. Alexandre and T. Ball 2005 International code for phytolith nomenclature. Annals of Botany 96:253-260.

Massal, E. and J. Barrau 1965 Food Plants of the South Sea Islands. New Caledonia: South Pacific Commission.

Middendorf, E.A. 1983 The remarkable shooting idioblasts. Aroideana 6(1):9-11.

Monje, P.V. and E.J. Baran 2002 Characterization of calcium oxalates generated as biominerals in cacti. Plant Physiology 128:707-713.

Nakata, P.A. 2003 Advances in our understanding of calcium oxalate crystal formation and function in plants. Plant Science 164:901-909.

Pallant, J. 2005 SPSS survival manual: a step by step guide to data analysis using SPSS for Windows (Version 12). Crows Nest: Allen and Unwin.

Piperno, D.R., A.J. Ranere, I. Holst and P. Hansell 2000 Starch grains reveal early crop horticulture in the Panamanian tropical forest. Nature 407(6808):894-897.

Piperno, D.R., E. Weiss, I. Holst and D. Nadel 2004 Processing of wild cereal grains in the Upper Palaeolithic revealed by starch grain analysis. Nature 430:670-673.

Prychid, C.J., R.S. Jabaily and P.A. Rudall In Press Cellular ultrastructure and crystal development in Amorphophallus (Araceae). Annals of Botany.

Prychid, C.J. and P.A. Rudall 1999 Calcium oxalate crystals in monocotyledons: a review of their structure and systematics. Annals of Botany 84:725-739. 
Sakai, W.S. and M. Hanson 1974 Mature raphid and raphid idioblast structure in plants of the edible aroid genera Colocasia, Alocasia, and Xanthosoma. Annals of Botany 38:739-748.

Sakai, W.S., M. Hanson and R.C. Jones 1972 Raphides with barbs and grooves in Xanthosoma sagittifolium (Araceae). Science 178:314-315.

Sakai, W.S., S.S. Shiroma and M.A. Nagao 1984 A study of raphide microstructure in relation to irritation. Scanning Electron Microscopy 1984(II):979-986.

Sunell, L.A. and P.L. Healey 1981 Scanning electron microscopy and energy dispersive x-ray analysis of raphide crystal idioblasts in taro. Scanning Electron Microscopy 1981(III):235244.

Tabachnick, B.G. and L.S. Fidell 1996 Using Multivariate Statistics. 3rd edn. New York: Harper Collins.

Therin, M., R. Torrence and R.L.K. Fullagar 1997 Australian Museum starch reference collection. Australian Archaeology 44:52-53.

Therin, M., R.L.K. Fullagar and R. Torrence 1999 Starch in sediments: a new approach to the study of subsistence and land use in Papua New Guinea. In C. Gosden and J.G. Hather (eds) The Prehistory of Food: Appetites for change, pp. 438-462. One World Archaeology Vol. 32. London: Routledge.

Tilton, V.R. and H.T. Horner, Jr 1980 Calcium oxalate raphide crystals and crystalliferous idioblasts in the carpels of Ornithogalum caudatum. Annals of Botany 46:533-539.

Torrence, R. 2006 Description, classification, and identification. In R. Torrence and H. Barton (eds) Ancient Starch Research, pp. 115-143. Walnut Creek, California: Left Coast Press.

Torrence, R., R. Wright and R. Conway 2004 Identification of starch granules using image analysis and multivariate techniques. Journal of Archaeological Science 31:519-532.

Wattendorff, J. 1976 A third type of raphide crystal in the plant kingdom: six-sided raphides with laminated sheaths in Agave americana L. Planta 130:303-311.

Webb, M.A. 1999 Cell-mediated crystallization of calcium oxalate in plants. Plant Cell 11:751761.

Webb, M.A., J.M. Cavaletto, N.C. Carpita, L.E. Lopez and H.J. Arnott 1995 The intravacuolar organic matrix associated with calcium oxalate crystals in leaves of Vitis. The Plant Journal 7(4):633-648.

Whistler, W.A. 1991 Polynesian plant introductions. In P.A. Cox and S.A. Banack (eds) Islands, Plants and Polynesians: An introduction to Polynesian Ethnobotany, pp. 41-66. Portland: Dioscorides Press.

Yen, D.E. 1974 Arboriculture in the subsistence of Santa Cruz, Solomon Islands. Economic Botany 28:237-243.

Yen, D.E. 1976 Agricultural systems and prehistory in the Solomon Islands. In R.C. Green and M. Cresswell (eds) Southeast Solomon Islands Cultural History, pp. 61-74. Bulletin 11. Wellington: The Royal Society of New Zealand.

Yen, D.E. 1991 Polynesian cultigens and cultivars: the question of origin. In P.A. Cox and S.A. Banak (eds) Islands, Plants and Polynesians: An introduction to Polynesian Ethnobotany, pp. 67-98. Portland: Dioscorides Press. 